OPEN ACCESS

Edited by:

Peter John Fraser,

University of Aberdeen,

United Kingdom

Reviewed by:

Carl L. Thurman,

University of Northern lowa,

United States

Wolfgang Stein,

Illinois State University, United States

Carolina Madeira,

Associação para a Inovação e Desenvolvimento da FCT

(NOVA.ID.FCT), Portugal

${ }^{*}$ Correspondence: John Campbell McNamara mcnamara@ffclrp.usp.br

${ }^{\dagger}$ Present address:

Samuel Coelho Faria, Centro de Biologia Marinha, Universidade de São Paulo,

São Sebastião, Brazi

Specialty section:

This article was submitted to Invertebrate Physiology, a section of the journal Frontiers in Physiology

Received: 30 May 2019 Accepted: 19 March 2020 Published: 24 April 2020

Citation:

Faria SC, Bianchini A, Lauer MM, Zimbardi ALRL, Tapella F, Romero MC and McNamara JC (2020) Living on the Edge: Physiological and Kinetic Trade-Offs Shape Thermal Tolerance in Intertidal Crabs From Tropical to Sub-Antarctic South America. Front. Physiol. 11:312. doi: 10.3389/fphys.2020.00312

\section{Living on the Edge: Physiological and Kinetic Trade-Offs Shape Thermal Tolerance in Intertidal Crabs From Tropical to Sub-Antarctic South America}

\author{
Samuel Coelho Faria ${ }^{1 \dagger}$, Adalto Bianchini², Mariana Machado Lauer², \\ Ana Lúcia Ribeiro Latorre Zimbardi3 ${ }^{3}$ Federico Tapella ${ }^{4}$, Maria Carolina Romero ${ }^{4}$ and \\ John Campbell McNamara ${ }^{1,5 *}$ \\ ${ }^{1}$ Departamento de Biologia, Faculdade de Filosofia, Ciências e Letras de Ribeirão Preto, Universidade de São Paulo, \\ Ribeirão Preto, Brazil, ${ }^{2}$ Instituto de Ciências Biológicas, Universidade Federal do Rio Grande, Rio Grande, Brazil, \\ ${ }^{3}$ Departamento de Química, Faculdade de Filosofia, Ciências e Letras de Ribeirão Preto, Universidade de São Paulo, \\ Ribeirão Preto, Brazil, ${ }^{4}$ Centro Austral de Investigaciones Científicas, CADIC-CONICET, Ushuaia, Argentina, ${ }^{5}$ Centro \\ de Biologia Marinha, Universidade de São Paulo, São Sebastião, Brazil
}

Temperature is an important abiotic factor that drives the evolution of ectotherms owing to its pervasive effects at all levels of organization. Although a species' thermal tolerance is environmentally driven within a spatial cline, it may be constrained over time due to differential phylogenetic inheritance. At the limits of thermal tolerance, hemolymph oxygen is reduced and lactate formation is increased due to mismatch between oxygen supply and demand; imbalance between enzyme flexibility/stability also impairs the ability to generate energy. Here, we characterized the effects of lower $\left(L_{50}\right)$ and upper $\left(U_{50}\right)$ critical thermal limits on selected descriptors of aerobic and anaerobic metabolism in 12 intertidal crab species distributed from northern Brazil $\left(\approx 7.8^{\circ} \mathrm{S}\right)$ to southern Patagonia $\left(\approx 53.2^{\circ} \mathrm{S}\right)$, considering their phylogeny. We tested for (i) functional trade-offs regarding aerobic and anaerobic metabolism and LDH kinetics in shaping thermal tolerance; (ii) influence of shared ancestry and thermal province on metabolic evolution; and (iii) presence of evolutionary convergences and adaptive peaks in the crab phylogeny. The tropical and subtropical species showed similar systemic and kinetic responses, both differing from the sub-Antarctic crabs. The lower UL50's of the sub-Antarctic crabs may reflect mismatch between the evolution of aerobic and anaerobic metabolism since these crabs exhibit lower oxygen consumption but higher lactate formation than tropical and subtropical species also at their respective UL50's. LDH activity increased with temperature increase, while $\mathrm{K}_{\mathrm{m}}{ }^{\mathrm{Pyr}}$ remained fairly constant; catalytic coefficient correlated negatively with thermal niche. Thermal tolerance may rely on a putative evolutionary trade-off between aerobic and anaerobic metabolism regarding energy supply, while temperature compensation of kinetic performance is driven by thermal habitat as revealed by the LDH affinity/efficiency equilibrium. The overall physiological evolution revealed two homoplastic adaptive peaks 
in the sub-Antarctic crabs with a further shift in the tropical/subtropical clade. The physiological traits at $\mathrm{UL}_{50}$ have evolved in a phylogenetic manner while all others were more plastic. Thus, shared inheritance and thermal environment have driven the crabs' thermal tolerance and metabolic evolution, revealing physiological transformations that have arisen in both colder and warmer climes, especially at higher levels of biological organization and phylogenetic diversity.

Keywords: evolutionary physiology, thermal adaptation, critical limits, oxygen consumption, lactate, LDH, Brachyura

\section{INTRODUCTION}

Biological systems are thermodynamically open, owing to the continuous flux of energy and matter with the surrounding environment (Cannon, 1929; Recordati and Bellini, 2004). Temperature is the main abiotic factor that drives the biogeographical evolution of ectotherms (Pörtner, 2002; Johns and Somero, 2004; Somero, 2004, 2010; Dong et al., 2008; Stevens et al., 2010; Tomanek and Zuzow, 2010) since it affects all levels of organization, from the subcellular to the systemic, including the intact organism. The deleterious effects of temperature often exceed the regulatory capability of an organism's homeostatic mechanisms, and thus limit the distribution of life, imposing constraints on biogeographical distributions.

In aquatic decapod crustaceans at usual habitat temperatures, the capacity for oxygen uptake by ventilation and its delivery by circulation matches the biochemical demands of the tissues for oxygen: the fully oxygenated hemolymph thus can sustain optimal aerobic metabolism in the tissues (Pörtner and Gutt, 2016; Verberk et al., 2016). However, at the critical thermal limits, hemolymph oxygen levels are reduced due to the mismatch between oxygen supply and demand, imposing limitations on temperature tolerance (Pörtner, 2002). This limitation to systemic oxygen availability creates a hypoxic state, which is unable to sustain tissue demand, leading to anaerobic metabolism at the critical thermal limits as a consequence of elevated oxygen demand or insufficient aerobic capacity (Giomi and Pörtner, 2013). The recruitment of chaperone molecules and anti-oxidant defenses may extend survival, albeit with reduced performance at the molecular level, reverberating at the whole animal level and leading to death. This unifying principle known as "oxygen and capacity limitation of thermal tolerance" (OCLTT) characterizes sensitivity to thermal stress in aquatic invertebrates (Pörtner and Gutt, 2016; Verberk et al., 2016). During aerial exposure, however, air-breathers and amphibious species can attain higher hemolymph oxygen concentrations and increase oxygen diffusion, which may enhance their thermal tolerance by extending aerobic scope (Giomi et al., 2014).

To illustrate, the spider crab Maja squinado exhibits highly oxygenated hemolymph between 8 and $17^{\circ} \mathrm{C}$, showing decreased oxygen partial pressures below $8^{\circ} \mathrm{C}$ and increased hemolymph lactate above $17^{\circ} \mathrm{C}$ (Frederich and Pörtner, 2000). The shore crabs Carcinus maenas and Cancer irroratus also accumulate hemolymph lactate at temperatures above 32 and $28^{\circ} \mathrm{C}$, respectively, after direct transfer from $12^{\circ} \mathrm{C}$ (Jost et al., 2012). The transition to a predominantly anaerobic metabolism in the lobster Homarus americanus takes place gradually and continuously, accompanying a progressive increase in hemolymph lactate, reaching a maximum at $30^{\circ} \mathrm{C}$ (Jost et al., 2012). Clearly, the limitation of oxygen supply to the tissues is linked to the onset of anaerobiosis due to a decreased capacity for oxygen uptake and transport. Further, patent patterns of increased oxygen demand and lactate formation are evident when temperature becomes life limiting.

Considering the subcellular environment, kinetic adjustments can result from oxygen- and capacity-limited thermal tolerance (Hochachka and Somero, 2002). Enzymes exhibit an inherent structural flexibility that guarantees their molecular function. However, they must also preserve the molecular rigidity that maintains their three-dimensional structure (Zavodszky et al., 1998). The balance between flexibility and stability in enzyme kinetics is temperature dependent, and is particularly evident with regard to lactate dehydrogenase $(\mathrm{LDH})$ in vertebrate species. $\mathrm{LDH}$ converts pyruvate to lactate during anaerobic metabolism, reflecting the ability to produce energy under critical thermal conditions as predicted by the OCLTT principle (Zakhartsev et al., 2004).

Comparative studies of LDH have explored certain lineages of ectothermal vertebrates and invertebrates from various thermal niches, although a phylogenetic approach has only been implemented in the latter. In response to increased temperature, vertebrate kinetic patterns show decreased binding capacity and increased catalytic efficiency (Fields and Somero, 1998; Hochachka and Somero, 2002; Somero, 2003, 2004). LDH activity tends to increase at higher temperatures as a consequence of the augmented energy available for the conformational changes required during catalysis (Dunn et al., 1991; Fields, 2001; Hochachka and Somero, 2002). These kinetic properties of ectothermal vertebrate enzymes reflect a highly competent or occasionally a marginally functional LDH, depending on thermal regime. In contrast, in invertebrates, particularly exemplified by species of the anomuran genus Petrolisthes, LDH thermal stability is not affected by maximum habitat temperature, suggesting likely phylogenetic constraints on interspecific variability in $\mathrm{LDH}$ stability (Stillman and Somero, 2001).

Considering environments that offer a wide thermal landscape, the continental shelves of the Americas are divided into sixteen zoogeographic provinces. These have been defined based on "part of the neritic zone with a relatively narrow range of temperatures where the fauna shows certain homogeneity," and particularly on oceanographic characteristics like water temperature and ocean currents (Boschi, 2000a,b; 
Boschi and Gavio, 2005). The eastern coast of South America embraces a significant thermal gradient and includes three provinces (Figure 1). The Brazilian province, between the mouth of the Orinoco river, Venezuela $\left(9^{\circ} \mathrm{N}\right)$ and Cabo Frio, Rio de Janeiro, southeastern Brazil (23을 (Briggs, 1974; Boschi, $2000 \mathrm{a}, \mathrm{b})$ in which mean surface water temperatures vary between 20.7 and $30.5^{\circ} \mathrm{C}$ (median $=26^{\circ} \mathrm{C}$ ). The Argentinian province, between Cabo Frio and Rawson, Chubut, central Argentina $\left(43-44^{\circ} \mathrm{S}\right)$ (Cooke, 1895; Boschi, 2000a), which exhibits temperatures between 7.0 and $27.5^{\circ} \mathrm{C}$ (median $=15^{\circ} \mathrm{C}$ ). And the Magellanic province, between Rawson and Tierra del Fuego (55 ${ }^{\circ}$ ), Patagonian Argentina (Carcelles and Williamson, 1951; Balech, 1954; Boschi, 2000a,b) in which temperatures vary between 4.0 and $18.0^{\circ} \mathrm{C}$ (median $=9^{\circ} \mathrm{C}$ ). These ranges represent the minimum and maximum mean monthly temperatures registered between 2009 and 2019 at the northern and southern geographical limits of each province (National Oceanic and Atmospheric Administration [NOAA] and U.S. Department of Commerce, 2019).

We have shown (Faria et al., 2017) that the micro-habitat temperatures (MHT) of some crab species from the Brazilian and Argentinian zoogeographical provinces are similar, but are higher than those of the Magellanic species. The upper $\left(\mathrm{UL}_{50}\right)$ and lower $\left(\mathrm{LL}_{50}\right)$ critical thermal limits of these crabs are subject to different environmental pressures, and exhibit unique evolutionary histories. The $\mathrm{UL}_{50}$ show phylogenetic signal and correlate with micro-habitat temperature, while the $L_{50}$ are more plastic and differ markedly among all provinces, revealing an asymmetrical evolutionary history of the critical thermal limits.

In the present study, we now investigate physiological and evolutionary patterns of thermal tolerance in this crab clade (Faria et al., 2017), characterizing the effects of critical thermal limits $\left(\mathrm{LL}_{50}\right.$ and $\mathrm{UL}_{50}$ ) on selected descriptors of aerobic and anaerobic metabolism at the systemic and kinetic levels. Using 12 intertidal crab species distributed across the three thermal provinces from northern Brazil to southern Patagonia, we tested for: (i) the influence of shared ancestry and thermal province on metabolic evolution; (ii) the existence of functional trade-offs among aerobic and anaerobic metabolism and LDH kinetics in shaping thermal tolerance; and (iii) the presence of evolutionary convergences and adaptive peaks in the crab phylogeny. This study considers that species' traits are linked to each other through space and time, embracing most dimensions of physiological evolution.

\section{MATERIALS AND METHODS}

\section{Crab Sampling and Laboratory Maintenance}

Approximately 70 adult, intermolt, male or female crabs of each of the 12 species were collected during the morning, at low tide, from mangroves, salt marshes, and sandy or rocky beaches, at the ends of the summers of 2013 and 2014. Collection sites included the Brazilian, Argentinian and Magellanic zoogeographical provinces (Boschi and Gavio, 2005;
Figure 1), which correspond roughly to the Tropical, Subtropical and sub-Antarctic physiographical zones.

In the laboratory, the crabs were maintained prior to experiments for 5 days in plastic boxes, each containing a thin layer of seawater $(\approx 3 \mathrm{~mm}$ deep, $30 \% \mathrm{~S}$ ) to allow gill wetting, in incubators or in water baths (Fanem 347 DCG; Solab SL 224; Polystat 12002, Palmer Instrument Company) at the respective field reference temperatures (FRT) of each zoogeographical province (see above). These temperatures represent the median of the mean monthly minimum and maximum temperatures registered at the northern and southern geographical limits of each province (sensu Boschi, 2000a; National Oceanic and Atmospheric Administration [NOAA] and U.S. Department of Commerce, 2019). This protocol also minimized possible intrinsic physiological variability related to the species' vertical positions within the intertidal habitat. The crabs were not fed during the experiments, and the seawater was replaced daily in the morning.

The tropical species (Aratus pisonii H. Milne Edwards, 1837; Cardisoma guanhumi Latreille, 1825; Goniopsis cruentata Latreille, 1803; Ocypode quadrata Fabricius, 1787; Pachygrapsus transversus Gibbes, 1850; Uca maracoani Latreille 1802-1803; and Ucides cordatus Linnaeus, 1763) were collected from beaches or mangroves on Ilha de Itamaracá or Itapissuma, Pernambuco (northeastern Brazil, $\approx 7.8^{\circ} \mathrm{S}, 34.8^{\circ} \mathrm{W}$ ). They were held at the FRT

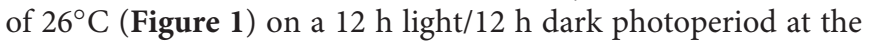
Universidade Federal de Pernambuco (Recife, Brazil).

The subtropical species (Armases rubripes Rathbun, 1897; Neohelice granulata Dana, 1851; and Leptuca uruguayensis Nobili, 1901) were collected from beaches near Rio Grande, Rio Grande do Sul (southern Brazil, $\approx 32.1^{\circ} \mathrm{S}, 52.1^{\circ} \mathrm{W}$ ). They were held at the FRT of $15^{\circ} \mathrm{C}$ (Figure 1) on a $14 \mathrm{~h}$ light $/ 10 \mathrm{~h}$ dark photoperiod at the Universidade Federal do Rio Grande (Rio Grande, Brazil).

The sub-Antarctic representatives (Acanthocyclus albatrossis Rathbun, 1898; and Halicarcinus planatus Fabricius, 1775) were collected from stony beaches near Ushuaia, Tierra del Fuego (southern Argentina, $\approx 53.2^{\circ} \mathrm{S}, 67.2^{\circ} \mathrm{W}$ ). They were held at the FRT of $9^{\circ} \mathrm{C}$ (Figure 1) on a $14 \mathrm{~h}$ light/10 h dark photoperiod, at the Centro Austral de Investigaciones Científicas, Consejo Nacional de Investigaciones Científicas y Técnicas (Ushuaia, Tierra del Fuego, Argentina).

\section{Critical Thermal Limits}

Lower $\left(\mathrm{LL}_{50}\right)$ and upper $\left(\mathrm{UL}_{50}\right)$ critical thermal limits and microhabitat temperatures for each of the species evaluated here have been published previously (Table 1; Faria et al., 2017). Both limits define the temperatures at which "the animal loses its ability to escape from conditions that will promptly lead to its death" (Cowles and Bogert, 1944). At each limit, 50\% of the crabs were unable to right themselves when placed in a supine position. This inability reflects the loss of key motor functions and/or potentially lethal, disorganized locomotory activity (Faria et al., 2017).

In brief, $\mathrm{LL}_{50}$ and $\mathrm{UL}_{50}$ were established $(8 \leq N \leq 10$ crabs per temperature and species) by direct transfer of the crabs to various lower or higher temperatures, respectively, from their respective FRT's $\left(26^{\circ} \mathrm{C}\right.$ for the tropical, $15^{\circ} \mathrm{C}$ for the subtropical, and $9^{\circ} \mathrm{C}$ 

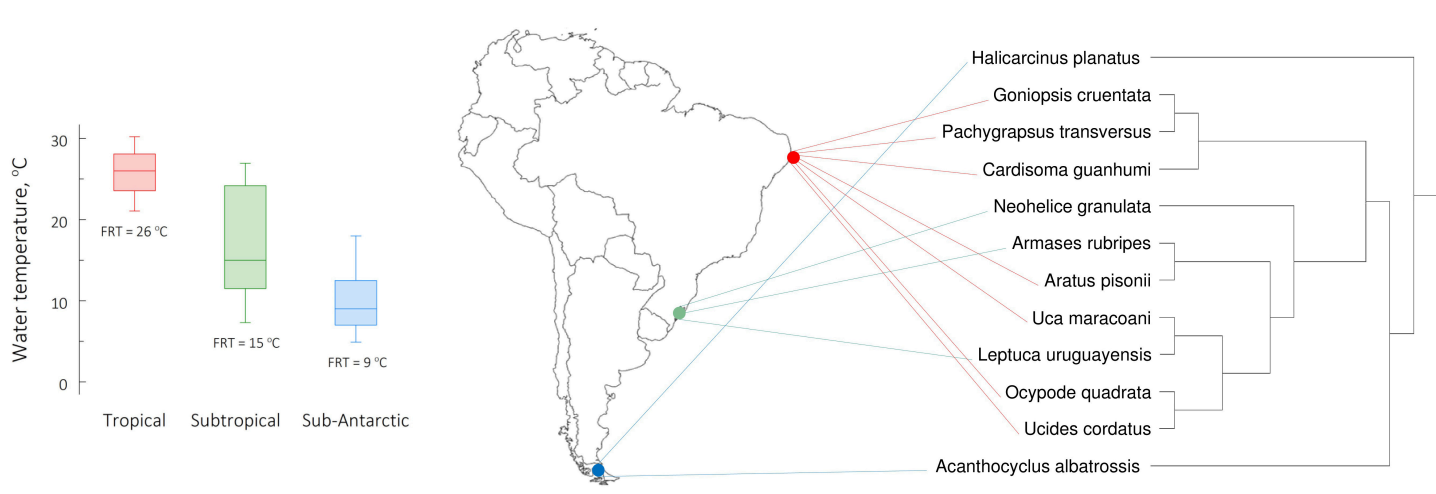

FIGURE 1 | Mean, monthly, maximum and minimum surface seawater temperatures registered between 2009 and 2019 (National Oceanic and Atmospheric Administration [NOAA] and U.S. Department of Commerce, 2019) (left pane/) at the northern and southern geographical limits, respectively, of each zoogeographical province along the eastern Atlantic coast of South America (sensu Boschi, 2000a). Surface seawater temperatures varied between 20.7 and $30.5^{\circ} \mathrm{C}$ for the Brazilian province, 7.0 and $27.5^{\circ} \mathrm{C}$ for the Argentinian province, and 4.0 and $18.0^{\circ} \mathrm{C}$ for the Magellanic province. The horizontal line within each box indicates the median temperature while the box boundaries show the interquartile values. Whiskers indicate the lowest and highest temperatures (range). Collecting site locations are indicated within each zoogeographical province (middle panel). The temperatures 26,15 , and $9^{\circ} \mathrm{C}$ represent the field reference temperatures (FRT) at which the crabs from each province were acclimated. The tropical species (Aratus pisonii, Cardisoma guanhumi, Goniopsis cruentata, Ocypode quadrata, Pachygrapsus transversus, Uca maracoani, and Ucides cordatus) were collected from the Brazilian province (northeastern Brazil, $\approx 7.8^{\circ} \mathrm{S}, 34.8^{\circ} \mathrm{W}$, red). The subtropical species (Armases rubripes, Neohelice granulata and Leptuca uruguayensis) were collected from the Argentinian province (southern Brazil, $\approx 32.1^{\circ} \mathrm{S}, 52.1^{\circ} \mathrm{W}$, green). The sub-Antarctic species (Acanthocyclus albatrossis and Halicarcinus planatus) were collected from the Magellanic province (southern Patagonia, $\approx 53.2^{\circ} \mathrm{S}, 67.2^{\circ} \mathrm{W}$, blue). The phylogenetic relationships among the species investigated (right panel) were generated employing a maximum likelihood search method using the mitochondrial 16 S ribosomal gene as a marker (see Faria et al., 2017).

for the sub-Antarctic species). The crabs were examined for $30 \mathrm{~s}$ every 30 min during a $6 \mathrm{~h}$ period. This duration of exposure represents "the mean emergence time of a crab at low tide" (Faria et al., 2017) and constitutes the mean duration of exposure to aerial temperatures during low tide.

This experimental design, i.e., direct exposure from the respective FRT to the $\mathrm{LL}_{50}$ or $\mathrm{UL}_{50}$ of each species, enabled quantitative measurement of the critical thermal limits of each species, in line with Faria et al.'s (2017) protocol. It thus allowed direct comparison and straightforward correlations between the critical thermal limits and the physiological traits evaluated.

\section{Mass-Specific Oxygen Consumption}

Individual crabs $(10 \leq N \leq 15)$ were placed into acrylic respirometer chambers containing a $3 \mathrm{~mm}$ deep layer of seawater $(30 \% \mathrm{~S})$, constructed specifically to accommodate each species with regard to diameter and volume. The respirometers were held in incubators or water baths (Fanem 347 DCG; Solab SL 224; Polystat 12002, Palmer Instrument Company) at the respective FRT of each species for a $12 \mathrm{~h}$ adjustment period prior to beginning the measurements. Each respirometer was coupled by plastic Crystal tubing to a multiplexing manometer and a gas analyzer (FoxBox-C Field Oxygen \& Carbon Dioxide Analysis System, Sable Systems International Inc.), and perfused with an airflow of from 150 to $600 \mathrm{~mL}$ $\mathrm{min}^{-1}$, depending on respirometer volume, standardized for each species. The standardized airflow provided a baseline percentage of atmospheric oxygen $\left(20.8 \% \mathrm{O}_{2}\right)$ in the absence of ambient pressure variation owing to the automated, barometric pressure compensation system.
After the $12 \mathrm{~h}$ adjustment period at the FRT, the respirometers were transferred to an incubator or water bath to measure $\mathrm{O}_{2}$ consumption at the $\mathrm{LL}_{50}$ or $\mathrm{UL}_{50}$ temperatures established previously for each species, using a stop-flow respirometric protocol (Steffensen, 1989). After a $4 \mathrm{~h}$ period of continuous airflow, the respirometers were sealed by closing their respective manometer valves for $\mathrm{a} \approx 2 \mathrm{~h}$ period. The $\mathrm{O}_{2}$ respired by each crab in each respirometer was then measured by recording the decrease in percentage oxygen compared to the pre-established baseline reading while renewing the airflow during a $6 \mathrm{~min}$ period of flushing to the gas analyzer. Since measurements were conducted at the critical thermal limits, some crabs died during the measurements. Only the lowest $\mathrm{O}_{2}$ consumption measurements recorded from at least 5-7 crabs alive at the end of each experiment were used.

After each experiment, each crab was cryoanesthetized in a freezer and killed by immersion for $20 \mathrm{~min}$ in crushed ice. The crabs were then dried in an oven at $60^{\circ} \mathrm{C}$ for up to $72 \mathrm{~h}$, and their dry masses were measured using an analytical balance ( $\pm 1 \mathrm{mg}$ precision).

Data acquisition software (Expedata, Sable Systems International Inc.) was used to calculate the integral of the area corresponding to the decrease in percentage oxygen $\left(\mathrm{I}_{\mathrm{A}}\right)$ in the flushed air. The individual mass-specific oxygen consumption rate $\left(\mathrm{QO}_{2}\right)$ for each crab was obtained from the formula:

$$
\begin{aligned}
& \mathrm{QO}_{2}\left(\mathrm{mLO}_{2} \mathrm{~g}^{-1} \mathrm{~h}^{-1}\right) \\
& \quad=\mathrm{I}_{\mathrm{A}} \times \mathrm{f}\left(\mathrm{mL} \mathrm{min}^{-1}\right) /[100 \times \mathrm{m}(\mathrm{g}) \times \mathrm{t}(\mathrm{min})] \times 60
\end{aligned}
$$

where $I_{A}$ is oxygen percentage area; $f$, airflow rate $(150-600 \mathrm{~mL}$ $\mathrm{min}^{-1}$ through each respirometer during the open phase); $\mathrm{m}$, 
TABLE 1 | Crab species collected from different zoogeographical provinces along the eastern Atlantic coast of South America, providing their microhabitat temperatures (MHT) and lower (LL50) and upper ( $\left.\mathrm{UL}_{50}\right)$ critical thermal limits (all in $\left.{ }^{\circ} \mathrm{C}\right)$ (modified from Faria et al., 2017).

\begin{tabular}{|c|c|c|c|c|}
\hline Species & Substrate & MHT & $\mathrm{LL}_{50}$ & $\mathrm{UL}_{50}$ \\
\hline \multicolumn{5}{|c|}{ Brazilian province (Tropical) } \\
\hline Aratus pisonii & Mangrove trees & $27.0 \pm 0.6$ & 12.8 & 36.9 \\
\hline Cardisoma guanhumi & Sandy-clay & $26.2 \pm 0.4$ & 13.4 & 38.6 \\
\hline Goniopsis cruentata & Mangrove mud & $28.2 \pm 0.8$ & 12.8 & 36.0 \\
\hline Ocypode quadrata & Sandy beaches & $21.8 \pm 0.8$ & 13.8 & 36.2 \\
\hline \multicolumn{4}{|l|}{ transversus } & 36.2 \\
\hline Uca maracoani & Mangrove mud & $36.3 \pm 0.5$ & 12.8 & 38.6 \\
\hline \multirow[t]{2}{*}{ Ucides cordatus } & Mangrove mud & $22.1 \pm 1.5$ & 15.5 & 39.0 \\
\hline & & $27.2 \pm 1.4$ & $13.6 \pm 0.4$ & $37.4 \pm 0.5$ \\
\hline \multicolumn{5}{|c|}{ Argentinian province (Subtropical) } \\
\hline Armases rubripes & Rocky shores & $27.0 \pm 1.2$ & 8.7 & 36.1 \\
\hline Neohelice granulata & Sandy-clay & $25.5 \pm 0.7$ & 6.5 & 36.7 \\
\hline \multirow[t]{2}{*}{ Uca uruguayensis } & Sandy beaches & $29.3 \pm 1.4$ & 10.4 & 39.3 \\
\hline & & $27.3 \pm 0.6$ & $8.5 \pm 1.1$ & $37.4 \pm 1.0$ \\
\hline \multicolumn{5}{|c|}{ Magellanic province (Sub-Antarctic) } \\
\hline $\begin{array}{l}\text { Acanthocyclus } \\
\text { albatrossis }\end{array}$ & Rocky shores & $1.5 \pm 0.1$ & -0.2 & 29.0 \\
\hline \multirow[t]{2}{*}{ Halicarcinus planatus } & Rocky shores & $1.4 \pm 0.1$ & -0.1 & 23.0 \\
\hline & & $1.5 \pm 0.1$ & $-0.2 \pm 0.1$ & $26.0 \pm 3.0$ \\
\hline
\end{tabular}

MHT data are the mean \pm SEM $(7 \leq N \leq 15)$. Data are independent of species' vertical positions (Stillman and Somero, 2000) within their intertidal zones (pGLS, $0.77 \leq F \leq 3.9,0.23 \leq P \leq 0.54$ ). Bold values are the mean $\pm S E M$ for all species in each province.

dry mass; $t$, duration of sealed phase. The factors " 100 " and "60" convert $\mathrm{O}_{2}$ percentage to $\mathrm{O}_{2}$ volume, and minutes to hours, respectively.

The effect of body mass on $\mathrm{QO}_{2}$ was removed by transforming the $\mathrm{QO}_{2}$ measurements into $\log _{10}$ values, which were then regressed against the respective dry masses. The residues of this regression were then employed, thus ensuring mass-free data.

\section{Extraction of Hemolymph and Abdominal Muscle Samples}

Specimens $(10 \leq N \leq 15)$ of each crab species were transferred from their respective FRT's to their respective $\mathrm{LL}_{50}$ and $\mathrm{UL}_{50}$ temperatures in incubators or water baths. After a $6 \mathrm{~h}$ exposure period at each thermal limit, a $50 \mu \mathrm{L}$ hemolymph sample was drawn through the arthrodial membrane at the base of the last pereiopod of the surviving crabs using a \#27-5 gauge needle coupled to an insulin syringe. Approximately $50 \mathrm{mg}$ of abdominal muscle were also dissected. All samples were frozen immediately in liquid nitrogen and transferred in dry ice to the Laboratory of Crustacean Physiology at the University of São Paulo in Ribeirão Preto where they were stored at $-80^{\circ} \mathrm{C}$ until analyses could be performed.

\section{Hemolymph Lactate}

Perchloric acid (6\%) was added to each hemolymph sample (3:1, $\mathrm{v} / \mathrm{v}$ ), followed by centrifugation at $10,000 \mathrm{~g}$ for $5 \mathrm{~min}$ at $4^{\circ} \mathrm{C}$. The supernatant was neutralized with $5 \mathrm{M} \mathrm{K}_{2} \mathrm{CO}_{3}(10: 1$, v/v) and recentrifuged. For microplate reading, an aliquot of each sample was added to a buffer containing $0.5 \mathrm{M}$ glycine, $0.4 \mathrm{M}$ hydrazine and $10 \mathrm{mM}$ EDTA at $\mathrm{pH}$ 9.0. $1 \mathrm{mM} \mathrm{NAD}^{+}$(final concentration) and $20 \mathrm{U} / \mathrm{mL} \mathrm{LDH}$ (final concentration) were added to each well, and the microplate was incubated at $25^{\circ} \mathrm{C}$ for $1 \mathrm{~h}$ in the dark and read at $340 \mathrm{~nm}$ (Bergmeyer and Bernt, 1974; Santos and Keller, 1993; Henry et al., 1994). The lactate concentration $\left(\mathrm{mg} \mathrm{L}^{-1}\right)$ was obtained from the formula:

$$
\begin{aligned}
& \text { Lactate concentration }\left(\mathrm{mg} \mathrm{L}^{-1}\right) \\
& \quad=\{[(\mathrm{A} \times 0.3)(6.22 \times 0.874 \times 0.015)] \times 3.4\} \times 90.1
\end{aligned}
$$

where A, Absorbance; 0.3, final fluid volume in each well; 6.22, molar extinction coefficient of NADH at $340 \mathrm{~nm}$; 0.874 , well optical path; 0.015 , sample volume in each well; 3.4, sample dilution factor; and 90.1, conversion factor from $\mathrm{mmol} \mathrm{L}-1$ to $\mathrm{mg} \mathrm{L}^{-1}$.

\section{Temperature Coefficient}

The effect of temperature on $\mathrm{QO}_{2}$ (aerobic sensitivity) and on lactate concentration (anaerobic sensitivity) was expressed using the formula $\mathrm{Q}_{10}=\left(\mathrm{k}_{1} / \mathrm{k}_{2}\right)^{10 /(\mathrm{t} 1-\mathrm{t} 2)}$, where $\mathrm{k}_{1}$ and $\mathrm{k}_{2}$ are the mass specific oxygen consumption rates at temperatures $t_{1}$ and $t_{2}$, respectively, where $t_{1}>t_{2}$. $Q_{1002}$ and $Q_{10 \text { Lac }}$ represent the temperature coefficients for changes in $\mathrm{QO}_{2}$ and hemolymph lactate, respectively.

\section{Muscle Lactate Dehydrogenase Kinetics}

Each abdominal muscle sample was homogenized (Eurostar Power-B, IKO Labortechnik) on crushed ice at 1,500 rpm for $60 \mathrm{~s}$ in $50 \mathrm{mM} \mathrm{K} \mathrm{HPO}_{4}$ buffer $\left(7: 1 \mathrm{v} / \mathrm{m}, \mathrm{mL} \mathrm{g}^{-1}\right.$, unadjusted $\mathrm{pH}$ ) (modified from Zietara et al., 1996). The homogenate was then centrifuged at $14,000 \mathrm{~g}$ for $40 \mathrm{~min}$ at $4^{\circ} \mathrm{C}$ and the supernatant was separated for enzyme kinetic assays. The LDH assays $(1 \leq N \leq 4$, pools of samples from 2 to 3 individual crabs) were performed using $100 \mathrm{~mL}$ of supernatant diluted from 10 to 2,000 times, depending on condition and species. This assay evaluates the oxidation of NADH to $\mathrm{NAD}^{+}$assuming steady-state conditions such as the linear relationship between $\mathrm{NAD}^{+}$formation and time (Segel, 1976). Controls without added homogenate were conducted to evaluate spontaneous NADH oxidation.

LDH activity was measured continuously, accompanying the oxidation of $\mathrm{NADH}$ to $\mathrm{NAD}^{+}$at $340 \mathrm{~nm}$ in thermostatted cells $\left(\varepsilon_{340 \mathrm{~nm}, \mathrm{pH}} 6.9=5,860 \mathrm{mM}^{-1} \mathrm{~cm}^{-1}\right.$; Cary $60 \mathrm{UV}-\mathrm{Vis}$ Spectrophotometer, Agilent Technologies) at both $25^{\circ} \mathrm{C}$ and at the respective FRT, $\mathrm{LL}_{50}$, and $\mathrm{UL}_{50}$ temperatures of each crab species for up to $5 \mathrm{~min}$. $\mathrm{LDH}$ activity was not measured at the $\mathrm{LL}_{50}$ 's of Acanthocyclus albatrossis and Halicarcinus planatus owing to the inability of the spectrophotometer to read at these low temperatures $\left(\approx-1^{\circ} \mathrm{C}\right)$.

For the kinetic assays, up to 14 pyruvate concentrations ranging from $1 \mu \mathrm{M}$ to $7 \mathrm{mM}$ were used in $80 \mathrm{mM}$ Imidazole$\mathrm{HCl}$ buffer at $\mathrm{pH} 6.9$, containing $150 \mu \mathrm{M}$ NADH in a final volume of $1 \mathrm{~mL}$ (modified from Stillman and Somero, 2001). The $\mathrm{pH}$ of the Imidazole buffer was adjusted according to 
the temperature of each assay. The kinetic parameters, i.e., maximum LDH activity $\left(\mathrm{V}_{\max }, \mathrm{U} \mathrm{mg}^{-1}\right)$, the Michaelis-Menten constant for pyruvate $\left(\mathrm{K}_{\mathrm{m}} \mathrm{Pyr}, \mathrm{mM}\right)$ and the catalytic coefficient $\left(\min ^{-1} 10^{3}\right)$ were calculated using the saturation curve for $\mathrm{LDH}$ activity against pyruvate concentration, employing the SigrafW application (Leone et al., 2005). $\mathrm{K}_{\mathrm{m}}{ }^{\mathrm{Pyr}}$ describes the enzymesubstrate affinity, representing the pyruvate concentration at which $\mathrm{LDH}$ activity is $\mathrm{V}_{\max } / 2$, indicating the ability to form an enzyme-substrate complex. The catalytic coefficient was measured at the FRT and was calculated for $25^{\circ} \mathrm{C}$ using a $\mathrm{Q}_{10}$ of 2 , reflecting a measure of the rates of enzyme-substrate formation and dissociation (Segel, 1976; Northrop, 1998) and, thus, the rate constant for transforming pyruvate (substrate) into lactate (product). $\mathrm{V}_{\max }$ also was calculated for $25^{\circ} \mathrm{C}$, using a $\mathrm{Q}_{10}$ of 2. One enzyme unit (U) is defined as the amount of $\mathrm{LDH}$ that hydrolyzes $1 \mathrm{mmol}$ of NADH per minute. Assays were performed in duplicate aliquots.

Total protein titers in the homogenates were measured following Read and Northcote (1981), using bovine serum albumin as the standard.

\section{Statistical Analyses}

For the intra-specific analyses, the effects of critical thermal limits on the systemic parameters $\mathrm{QO}_{2}$, lactate concentration and their respective $Q_{10}$ 's, and on the kinetic parameters $V_{\text {max }}$ and $K_{m} P y r$, for each species, were evaluated using a one-way Analysis of Variance followed by the Student-Newman-Keuls (SNK) multiple means comparison procedure to detect differences among groups $(P \leq 0.05)$. Data are expressed as the mean \pm SEM.

Inter-specific comparisons were conducted based on a molecular phylogenetic analysis of 36 species, performed by a maximum likelihood procedure using the $16 \mathrm{~S}$ ribosomal gene (Faria et al., 2017), a marker commonly used in phylogenetic studies of decapod Crustacea (e.g., Schubart et al., 2000; Mantelatto et al., 2009a,b; Pileggi and Mantelatto, 2010). Briefly, the phylogenetic analysis was undertaken using the Maximum Likelihood search method (Felsenstein, 1973, 1981) developed in RAxML 7.2.7 (Stamatakis, 2006) and implemented on the CIPRES system, employing the GTR $+\int+$ I substitution model (Tavaré, 1986). A rapid bootstrap method (1,000 replicates) (Stamatakis et al., 2008) was used to evaluate topology consistency, only confidence values greater than 50\% being considered. The original tree was pruned, maintaining only those species physiologically evaluated here. Branch lengths reflect genetic divergence.

The hypothesis that zoogeographical province may have affected the evolution of the physiological traits at the FRT, LL $L_{50}$, or $\mathrm{UL}_{50}$ was tested using Phylogenetic Generalized Least Squares (PGLS) models. PGLS assumes that the residual variation among species is correlated owing to their shared ancestry (Grafen, 1989; Garland and Ives, 2000; Lavin et al., 2008), following a hierarchical disposition through time. Since character evolution is mathematically modeled along each branch of the phylogeny, we tested two evolutionary models simultaneously for each PGLS, employing the $\alpha$ parameter. The $\alpha$-value is a measure of the selection strength that constrains a trait toward an optimum value: unconstrained character evolution $(\alpha=0)$ is best fitted by the "Brownian motion" evolutionary model, while trait evolution with weakly limited or unlimited minimum and maximum values is best represented by the "Ornstein-Uhlenbeck" (O-U) model of evolution (Revell, 2010). This procedure was performed to ensure the best-adjusted evolutionary correlation for each set of inter-specific data.

Phylogenetic signal, a measure of the tendency of closely related species to resemble each other more than those drawn randomly from a clade, was calculated using Abouheif's test (Abouheif, 1999; Pavoine et al., 2008). An independent Monte Carlo test was conducted for each trait to provide its Moran's $I$ index and respective P-value. Moran's $I$ varies from -1 to +1 , revealing physiological dissimilarities and similarities, respectively, between closely related species (Gittleman and Kot, 1990; Diniz-Filho, 2001).

Overall physiological variability was analyzed using a phylogenetic principal components analysis (pPCA; Jombart et al., 2010). The phylogenetic structure of the multivariate comparative data was obtained by including all measured traits simultaneously (except $\mathrm{V}_{\max }$ and $\mathrm{K}_{\mathrm{m}}{ }^{\text {Pyr }}$ for the sub-Antarctic species where data were unavailable), including microhabitat temperature and both critical thermal limits, for all species. The scores of the two main dimensions $\left(\mathrm{PC}_{1}\right.$ and $\left.\mathrm{PC}_{2}\right)$ for each species were then plotted against the phylogeny.

We also tested for the presence of convergent evolutionary events using the SURFACE method (Ingram and Mahler, 2013) to evaluate whether the hypothesis of physiological shifts among the three zoogeographic provinces is more likely than that expected by chance. Comparisons among several simulated $\mathrm{O}-\mathrm{U}$ models were performed using the stepwise Akaike Information Criterion (AIC) procedure, and all improvements in AIC values were considered.

Comparative analyses were conducted using the $\mathrm{R}$ environment ( $\mathrm{R}$ Development Core Team, 2019), specifically ape (Paradis et al., 2004), nlme (Pinheiro et al., 2015), phytools (Revell, 2012), adephylo (Jombart et al., 2010), and SURFACE (Ingram and Mahler, 2013) packages. $P$-values were set at 0.05 .

Our findings can be considered free of bias from the species' vertical positions within their intertidal zones since this parameter had no effect on any physiological trait (pGLS ANOVA, $0.77 \leq F \leq 3.9,0.23 \leq P \leq 0.54$ ). Our characterization of the vertical distributions assumed the five categories distinguished by Stillman and Somero (2000).

\section{RESULTS}

\section{Thermal Effects on Systemic Metabolism: $\mathbf{Q O}_{2}$, Hemolymph Lactate and $Q_{10}$}

The subtropical species Neohelice granulata and Armases rubripes exhibited the lowest $\left(0.01 \pm 0.00 \mathrm{mLO}_{2} \mathrm{~g}^{-1} \mathrm{~h}^{-1}\right)$ and highest $\mathrm{QO}_{2}$ 's $\left(0.97 \pm 0.08 \mathrm{mLO}_{2} \mathrm{~g}^{-1} \mathrm{~h}^{-1}\right)$ at their respective $\mathrm{LL}_{50}$ $\left(6.5^{\circ} \mathrm{C}\right)$ and $\mathrm{UL}_{50}\left(36.1^{\circ} \mathrm{C}\right)$ (Table 2 and Figure 2). Both these species also showed the most sensitive $\mathrm{QO}_{2}$ 's $\left(\mathrm{Q}_{1002}\right.$ 's of 3.7 and 3.1, respectively). Interestingly, the sub-Antarctic species 
TABLE 2 | Crab species and their systemic physiological parameters, mass-specific oxygen consumption rate $\left(\mathrm{mL} \mathrm{O}_{2} \mathrm{~g}^{-1} \mathrm{~h}^{-1}\right)$ and hemolymph lactate concentration $\left(m g L^{-1}\right)$, measured at their respective field reference temperatures (FRT) and lower $\left(L_{50}\right)$ and upper $\left(U_{50}\right)$ critical thermal limits.

\begin{tabular}{|c|c|c|c|c|c|c|c|}
\hline \multirow[t]{2}{*}{ Species } & \multicolumn{3}{|c|}{$\begin{array}{l}\mathrm{O}_{2} \text { consumption } \\
\left(\mathrm{mLO}_{2} \mathrm{~g}^{-1} \mathrm{~h}^{-1}\right)\end{array}$} & \multicolumn{3}{|c|}{$\begin{array}{l}\text { Hemolymph lactate } \\
\qquad\left(\mathrm{mg} \mathrm{L}^{-1}\right)\end{array}$} & \multirow{2}{*}{$\begin{array}{l}\text { Temperature } \\
\text { coefficients } \\
\mathrm{Q}_{10} \mathrm{O}_{2} / \mathrm{Q}_{10 \mathrm{Lac}}\end{array}$} \\
\hline & $\mathbf{L L}_{50}$ & FRT & $\mathrm{UL}_{50}$ & $\mathbf{L L}_{50}$ & FRT & $\mathrm{UL}_{50}$ & \\
\hline \multicolumn{8}{|l|}{ Brazilian province (Tropical) } \\
\hline Aratus pisonii & $0.14 \pm 0.03^{\star}$ & $0.49 \pm 0.06$ & $0.95 \pm 0.22^{\star}$ & $62 \pm 7$ & $61 \pm 2$ & $177 \pm 35^{\star}$ & $2.2 / 1.6$ \\
\hline Cardisoma guanhumi & $0.11 \pm 0.02^{*}$ & $0.37 \pm 0.11$ & $0.62 \pm 0.08^{\star}$ & $41 \pm 6^{\star}$ & $174 \pm 30$ & $167 \pm 38$ & $2.1 / 1.9$ \\
\hline Goniopsis cruentata & $0.13 \pm 0.04^{*}$ & $0.38 \pm 0.07$ & $0.87 \pm 0.14^{*}$ & $62 \pm 6^{\star}$ & $153 \pm 27$ & $231 \pm 26^{\star}$ & $2.4 / 1.8$ \\
\hline Ocypode quadrata & $0.15 \pm 0.04^{*}$ & $0.39 \pm 0.09$ & $0.86 \pm 0.10^{*}$ & $25 \pm 3$ & $90 \pm 33$ & $172 \pm 34$ & $2.1 / 2.2$ \\
\hline Pachygrapsus transversus & $0.14 \pm 0.03^{\star}$ & $0.54 \pm 0.10$ & $0.90 \pm 0.09^{\star}$ & $136 \pm 19$ & 146 & $144 \pm 50$ & $2.3 / 1.0$ \\
\hline Uca maracoani & $0.05 \pm 0.00^{\star}$ & $0.29 \pm 0.07$ & $0.45 \pm 0.10^{*}$ & $37 \pm 4$ & $93 \pm 25$ & $137 \pm 29$ & $2.5 / 1.7$ \\
\hline \multirow[t]{2}{*}{ Ucides cordatus } & $0.17 \pm 0.05$ & $0.20 \pm 0.07$ & $0.87 \pm 0.13^{*}$ & $54 \pm 10$ & $76 \pm 31$ & $222 \pm 63^{*}$ & $2.1 / 1.9$ \\
\hline & $0.13 \pm 0.02^{\star}$ & $0.38 \pm 0.11$ & $0.78 \pm 0.07^{\star}$ & $60 \pm 14^{*}$ & $128 \pm 25$ & $179 \pm 14^{*}$ & $2.3 / 1.7$ \\
\hline \multicolumn{8}{|c|}{ Argentinian province (Subtropical) } \\
\hline Armases rubripes & $0.05 \pm 0.01$ & $0.05 \pm 0.01$ & $0.97 \pm 0.08^{*}$ & $94 \pm 19$ & $95 \pm 30$ & $138 \pm 29$ & $3.1 / 1.2$ \\
\hline Neohelice granulata & $0.01 \pm 0.00^{\star}$ & $0.07 \pm 0.02$ & $0.44 \pm 0.05^{\star}$ & $29 \pm 6$ & $21 \pm 3$ & $73 \pm 19^{*}$ & $3.7 / 1.4$ \\
\hline \multirow[t]{2}{*}{ Leptuca uruguayensis } & $0.06 \pm 0.02$ & $0.07 \pm 0.01$ & $0.94 \pm 0.13^{*}$ & $6 \pm 2$ & $10 \pm 3$ & $11 \pm 2$ & $2.3 / 1.2$ \\
\hline & $0.04 \pm 0.02$ & $0.06 \pm 0.01$ & $0.78 \pm 0.30^{\star}$ & $43 \pm 26$ & $42 \pm 27$ & $74 \pm 37^{\star}$ & $3.0 / 1.3$ \\
\hline \multicolumn{8}{|c|}{ Magellanic province (Sub-Antarctic) } \\
\hline Acanthocyclus albatrossis & $0.03 \pm 0.01^{\star}$ & $0.11 \pm 0.03$ & $0.37 \pm 0.03^{\star}$ & $23 \pm 2$ & $26 \pm 5$ & $1,564 \pm 255^{\star}$ & $2.5 / 4.6$ \\
\hline \multirow[t]{2}{*}{ Halicarcinus planatus } & $0.03 \pm 0.00^{\star}$ & $0.11 \pm 0.01$ & $0.22 \pm 0.03^{\star}$ & $19 \pm 3^{\star}$ & $33 \pm 5$ & $747 \pm 88^{\star}$ & $2.5 / 5.4$ \\
\hline & $0.03 \pm 0.00^{\star}$ & $0.11 \pm 0.00$ & $0.30 \pm 0.11^{\star}$ & $21 \pm 2^{*}$ & $30 \pm 4$ & $1,155 \pm 409^{\star}$ & $2.5 / 5.0$ \\
\hline
\end{tabular}

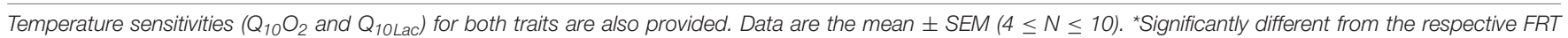
value (ANOVA, SNK, $P \leq 0.05$ ). Bold values are the mean \pm SEM for all species in each province.

Acanthocyclus albatrossis and Halicarcinus planatus at the FRT of $9^{\circ} \mathrm{C}$ exhibited higher $\mathrm{QO}_{2}$ 's $\left(\approx 0.11 \mathrm{mLO}_{2} \mathrm{~g}^{-1} \mathrm{~h}^{-1}\right)$ than all the subtropical representatives (Armases rubripes, $N$. granulata and Leptuca uruguayensis $\left[\approx 0.06 \mathrm{mLO}_{2} \mathrm{~g}^{-1} \mathrm{~h}^{-1}\right]$ ) at the FRT of $15^{\circ} \mathrm{C}$ (Table 2).

The lowest hemolymph lactate concentration ([Lac]) was found in the subtropical species Leptuca uruguayensis $(6 \pm 2 \mathrm{mg} / \mathrm{L})$ at its $\mathrm{LL}_{50}$ of $10.4^{\circ} \mathrm{C}$. The sub-Antarctic species $A$. albatrossis showed the highest concentrations $\left(1,564 \pm 255 \mathrm{mg} / \mathrm{L}\right.$, respectively) at its $\mathrm{UL}_{50}$ of $29^{\circ} \mathrm{C}$ (Figure 3 ). $\mathrm{Q}_{10 \mathrm{Lac}}$ values consistently fell between 1.2 and 1.9, the highest values being found in the sub-Antarctic species, particularly H. planatus (5.4) (Table 2).

Critical temperatures affected mean $\mathrm{QO}_{2}$ (ANOVA $20 \leq F \leq 46, P \leq 0.004$ ) and mean hemolymph [Lac] (ANOVA, $16 \leq F \leq 25, P \leq 0.05)$ in the tropical and Sub-Antarctic species. These traits increased at the respective mean $\mathrm{UL}_{50}$ 's of $\approx 37$ and $\approx 26^{\circ} \mathrm{C}$ and diminished at the mean $\mathrm{LL}_{50}$ 's of $\approx 14^{\circ} \mathrm{C}$ and $\approx 0^{\circ} \mathrm{C}$, both compared to the FRT's of 26 and $9^{\circ} \mathrm{C}$, respectively (SNK, $P \leq 0.05$ ) (Table 2). However, for the subtropical representatives, the mean $\mathrm{QO}_{2}$ 's and mean hemolymph [Lac] were similar when comparing these rates at the FRT of $15^{\circ} \mathrm{C}$ and the mean $\mathrm{LL}_{50}$ of $\approx 9^{\circ} \mathrm{C}(\mathrm{SNK}, P=0.23)$, demonstrating that metabolism was unchanged during cooling. Values were higher, however, at the mean $\mathrm{UL}_{50}$ of $\approx 37^{\circ} \mathrm{C}(\mathrm{SNK}, P \leq 0.05)$.

\section{Evolutionary and Comparative Patterns}

Zoogeographical province affected the evolution of $\mathrm{QO}_{2}$ under all three thermal regimes (pGLS ANOVA, $9 \leq F \leq 18$,
$P \leq 0.02,0.14 \leq \alpha \leq 21)$. At the FRT of $26^{\circ} \mathrm{C}$, tropical species showed a higher mean $\mathrm{QO}_{2}\left(0.38 \pm 0.11 \mathrm{mLO}_{2}\right.$ $\left.\mathrm{g}^{-1} \mathrm{~h}^{-1}\right)$ than subtropical $\left(0.06 \pm 0.01 \mathrm{mLO}_{2} \mathrm{~g}^{-1} \mathrm{~h}^{-1} 1\right)$ and sub-Antarctic $\left(0.11 \pm 0.00 \mathrm{mLO}_{2} \mathrm{~g}^{-1} \mathrm{~h}^{-1}\right)$ species, which also differed between their respective FRT's of 15 and $9^{\circ} \mathrm{C}$, respectively (phyHolm-Bonferroni, $P=0.05$ ) (Table 2 ). Further, mean $\mathrm{QO}_{2}$ 's at the critical temperature limits showed different evolutionary patterns. Mean $\mathrm{QO}_{2}$ at the mean $\mathrm{UL}_{50}$ was lower in the sub-Antarctic species $\left(0.30 \pm 0.11 \mathrm{mLO}_{2}\right.$ $\left.\mathrm{g}^{-1} \mathrm{~h}^{-1}\right)$ than in the tropical $\left(0.88 \pm 0.13 \mathrm{mLO}_{2} \mathrm{~g}^{-1} \mathrm{~h}^{-1}\right)$ and subtropical $\left(0.78 \pm 0.3 \mathrm{mLO}_{2} \mathrm{~g}^{-1} \mathrm{~h}^{-1}\right)$ representatives (phyHolm-Bonferroni, $P=0.02$ ) (Figure 4). However mean $\mathrm{QO}_{2}$ was similar $\left(\approx 0.07 \mathrm{mLO}_{2} \mathrm{~g}^{-1} \mathrm{~h}^{-1}\right)$ for all provinces at the mean $\mathrm{LL}_{50}$ (phyHolm-Bonferroni, $P \geq 0.68$ ). The evolution of $\mathrm{Q}_{10}$ was not driven by thermal regime (pGLS ANOVA, $F \leq 3.3, P \geq 0.1$ ), showing a mean sensitivity of 2.5 (Table 2).

In contrast, zoogeographical province affected the evolution of hemolymph [Lac] only at the mean $\mathrm{UL}_{50}$ (pGLS ANOVA, $F=7.9, P \leq 0.05,44 \leq \alpha \leq 47)$. Mean hemolymph [Lac] for the sub-Antarctic species was greater $\left(1,155 \pm 409 \mathrm{mg} \mathrm{L}^{-1}\right)$ than those of the tropical $\left(179 \pm 14 \mathrm{mg} \mathrm{L}^{-1}\right)$ and subtropical $(74 \pm 37 \mathrm{mg} / \mathrm{L})$ representatives (phyHolm-Bonferroni, $P \leq 0.05$ ), the values for the latter groups being similar (phyHolmBonferroni, $P \geq 0.05$ ) (Table 2 and Figure 4). Mean hemolymph [Lac] at the mean $\mathrm{LL}_{50}\left(49 \pm 11 \mathrm{mg} \mathrm{L}^{-1}\right.$, all species $)$ and at the FRT (90 $\pm 21 \mathrm{mg} \mathrm{L}^{-1}$, all species) were similar among provinces (phyHolm-Bonferroni, $P \geq 0.05$ ). Mean $\mathrm{Q}_{10}$ 's for hemolymph lactate mirrored this similarity (pGLS ANOVA, 


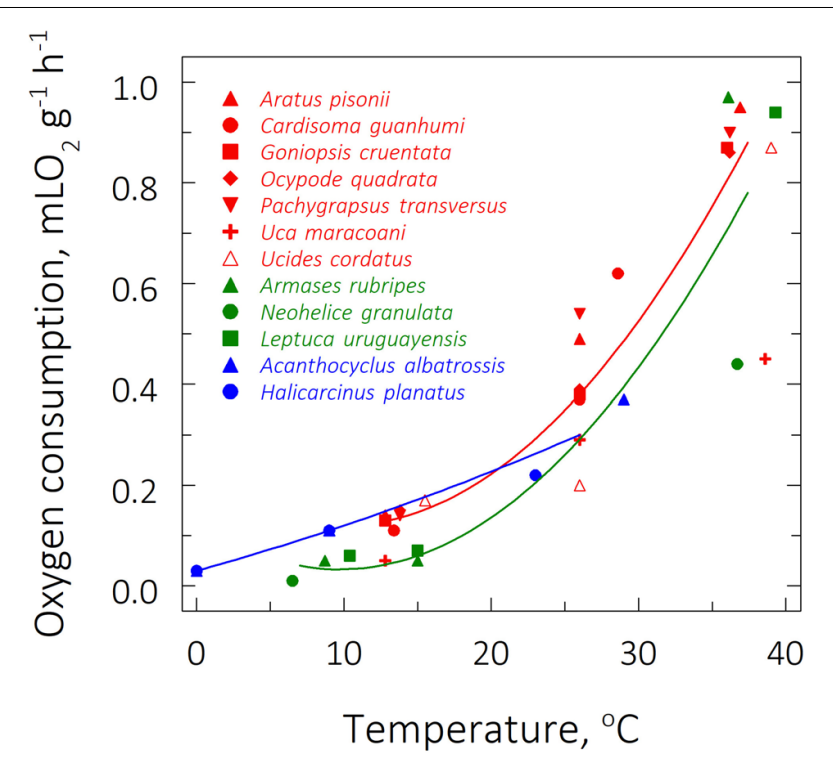

FIGURE 2 | Effect of direct transfer of tropical (red), subtropical (green), and sub-Antarctic (blue) crab species on mass-specific oxygen consumption rate $\left(\mathrm{QO}_{2}\right)$ after $6 \mathrm{~h}$ exposure to their respective upper and lower critical thermal limits, from their corresponding field reference temperatures of 26,15 , and $9^{\circ} \mathrm{C}$. Data $\left(\mathrm{mL} \mathrm{O}_{2} \mathrm{~g}^{-1} \mathrm{~h}^{-1}\right)$ are mean values $(6 \leq N \leq 9)$ and were adjusted to a second degree polynomial curve.

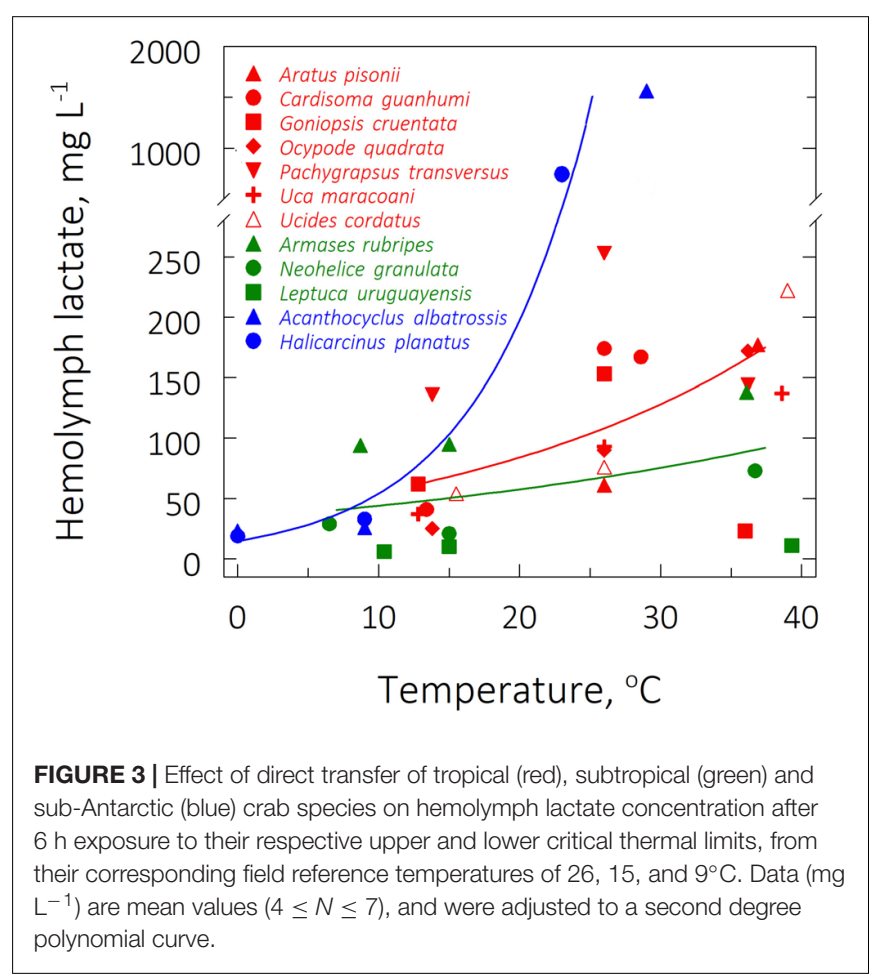

$7.5 \leq F \leq 7.8, P \leq 0.05)$, being greater in the sub-Antarctic species $(3.9 \pm 1.5)$ than in the tropical $(1.7 \pm 0.1)$ and subtropical species $(1.3 \pm 0.1)$.

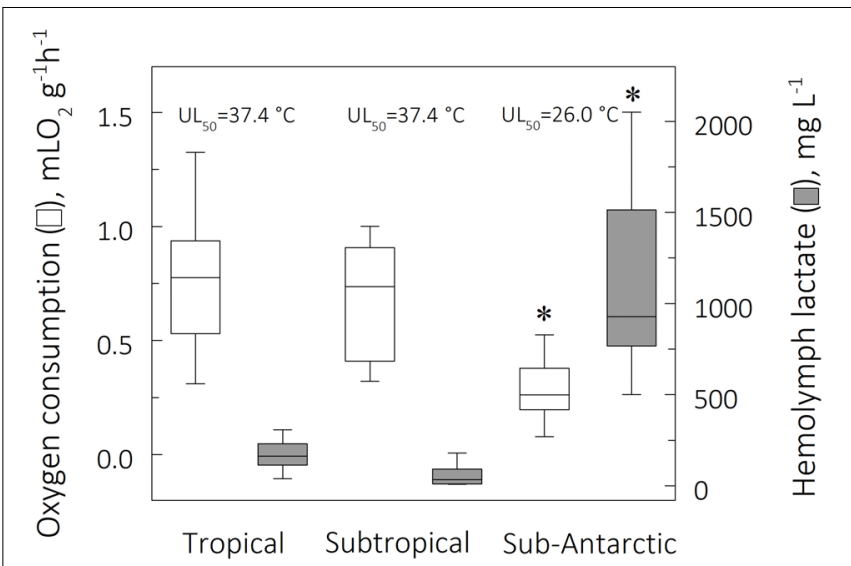

FIGURE 4 | Mean mass-specific oxygen consumption $\left(\mathrm{QO}_{2}, \mathrm{~mL} \mathrm{O}_{2} \mathrm{~g}^{-1} \mathrm{~h}^{-1}\right)$ and mean hemolymph lactate concentrations $\left(\mathrm{mg} \mathrm{L}^{-1}\right)$ for tropical, subtropical and sub-Antarctic crab species at their respective $U_{50}$, after $6 \mathrm{~h}$ direct transfer from their corresponding field reference temperatures of 26, 15 , and $9^{\circ} \mathrm{C}$. The horizontal line within each box indicates the median $\mathrm{QO}_{2}$ while the box boundaries show the interquartile values. Whiskers indicate the lowest and highest $\mathrm{QO}_{2}$ 's (range). Specimens (12 $\leq N \leq 41$ per species) for all species sampled from each zoogeographical province were used to provide the plots. *Significantly different from tropical and subtropical species (phyHolm-Bonferroni, $P \leq 0.05$ ).

\section{Thermal Effects on Muscle LDH Kinetics: $\mathbf{V}_{\max }, \mathrm{K}_{\mathbf{m}}{ }^{\text {Pyr }}$ and Catalytic Coefficient}

The highest $\mathrm{V}_{\max }$ was $7.43 \pm 0.39 \mathrm{U} \mathrm{mg}^{-1}$ for the tropical species Ucides cordatus at its $\mathrm{UL}_{50}$ of $39.0^{\circ} \mathrm{C}$ while the lowest activity was $0.09 \pm 0.00 \mathrm{U} \mathrm{mg}^{-1}$ in the sub-Antarctic species Halicarcinus planatus at the FRT of $9.0^{\circ} \mathrm{C}$ (Table 3 and Figure 5). At the zoogeographical province level, the mean $\mathrm{V}_{\max }$ 's for the tropical and subtropical species were strongly sensitive to critical temperature exposure: $\mathrm{V}_{\max }$ 's were higher at the mean $\mathrm{UL}_{50}$ and lower at the mean $\mathrm{LL}_{50}$ (ANOVA; $11.5 \leq F \leq 15.2 ; P \leq 0.01$ ). The mean $\mathrm{V}_{\max }$ for the subAntarctic species was thermally insensitive (ANOVA; $F=1.0$; $P=0.4)$. At an extrapolated temperature of $25^{\circ} \mathrm{C}$, mean $\mathrm{V}_{\max }$ values were affected by zoogeographical province (pGLS ANOVA, $F=6.0, P=0.05, \alpha=16.9)$ with calculated values of $1.7 \pm 0.3,1.1 \pm 0.1$ and $0.6 \pm 0.3 \mathrm{U} \mathrm{mg}^{-1}$ for the tropical, subtropical and sub-Antarctic species, respectively (Table 3 and Figure 5, insert).

Mean $\mathrm{K}_{\mathrm{m}}^{\text {Pyr }}$ for the subtropical and sub-Antarctic crab species were not affected by exposure at their critical thermal limits (ANOVA, $0.62 \leq F \leq 0.95 ; P \geq 0.43$ ) (Table 3). However, mean $\mathrm{K}_{\mathrm{m}}{ }^{\text {Pyr }}$ for the tropical species was affected by exposure at the mean $\mathrm{UL}_{50}$ (ANOVA, $F=4.6, P \leq 0.05$; SNK, $P \leq 0.05$ ). The mean $\mathrm{K}_{\mathrm{m}}{ }^{\mathrm{Pyr}}$ for the three provinces under all thermal regimes was $0.3 \mathrm{mM}$ (Figure 6). In contrast, the catalytic coefficients calculated for $25^{\circ} \mathrm{C}\left(3.0-26.5 \mathrm{~min}^{-1} 10^{3}\right.$; Figure 5, insert) did regress on microhabitat temperatures (pGLS, $-0.62 \leq$ slope $\leq-0.64,5.4 \leq F \leq 8.8, P \leq 0.05$, $\alpha=22.9$ ), when the sub-Antarctic species A. albatrossis and $H$. planatus are excluded from the analysis (see also Table 3). 
TABLE 3 | Crab species and their kinetic parameters, LDH activity $\left(V_{\text {max }}, U \mathrm{mg}^{-1}\right)$ and $\mathrm{K}_{\mathrm{m}}{ }^{\text {Pyr }}(\mathrm{mM})$, measured at their respective field reference temperatures (FRT) and lower $\left(L_{50}\right)$ and upper $\left(U_{50}\right)$ critical thermal limits.

\begin{tabular}{|c|c|c|c|c|c|c|c|}
\hline \multirow[t]{2}{*}{ Species } & \multicolumn{3}{|c|}{$\begin{array}{c}\text { LDH activity } \\
\left(\mathrm{V}_{\max }, \mathrm{U} \mathrm{mg}^{-1}\right)\end{array}$} & \multicolumn{3}{|c|}{$\begin{array}{l}K_{m}{ }^{P y r} \\
(m M)\end{array}$} & \multirow{2}{*}{$\begin{array}{c}\begin{array}{c}\text { Catalytic coefficient } \\
\left(\mathrm{min}^{-1} 10^{3}\right)\end{array} \\
25^{\circ} \mathrm{C}\end{array}$} \\
\hline & $\mathrm{LL}_{50}$ & FRT & $\mathrm{UL}_{50}$ & $\mathrm{LL}_{50}$ & FRT & $\mathrm{UL}_{50}$ & \\
\hline \multicolumn{8}{|c|}{ Brazilian province (Tropical) } \\
\hline Aratus pisonii & $0.33 \pm 0.02^{\star}$ & $1.27 \pm 0.10$ & $2.56 \pm 0.04^{\star}$ & $0.06 \pm 0.00^{\star}$ & $0.11 \pm 0.00$ & $0.20 \pm 0.00^{\star}$ & 10.6 \\
\hline Cardisoma guanhumi & $1.11 \pm 0.17^{\star}$ & $3.75 \pm 0.16$ & $6.04 \pm 0.03^{\star}$ & $0.22 \pm 0.03^{\star}$ & $0.17 \pm 0.01$ & $0.61 \pm 0.01^{\star}$ & 20.2 \\
\hline Goniopsis cruentata & $0.48 \pm 0.13$ & 1.15 & 2.28 & $0.06 \pm 0.01$ & 0.10 & 0.2 & 10.6 \\
\hline Ocypode quadrata & $0.66 \pm 0.06^{*}$ & $2.57 \pm 0.11$ & $5.70 \pm 1.81$ & $0.08 \pm 0.00^{*}$ & $0.15 \pm 0.02$ & $0.36 \pm 0.04$ & 16.7 \\
\hline Pachygrapsus transversus & $0.49 \pm 0.12^{\star}$ & $1.17 \pm 0.09$ & $2.56 \pm 0.04^{*}$ & $0.22 \pm 0.00$ & $0.20 \pm 0.01$ & $0.29 \pm 0.00^{*}$ & 5.4 \\
\hline Uca maracoani & $0.94 \pm 0.04^{\star}$ & $1.94 \pm 0.09$ & $4.73 \pm 0.31^{\star}$ & $0.37 \pm 0.01$ & $0.49 \pm 0.05$ & $0.57 \pm 0.09$ & 3.5 \\
\hline \multirow[t]{2}{*}{ Ucides cordatus } & $2.4 \pm 0.4^{\star}$ & $4.70 \pm 0.10$ & $7.43 \pm 0.39^{\star}$ & $0.17 \pm 0.03$ & $0.17 \pm 0.01$ & $0.34 \pm 0.01^{*}$ & 26.5 \\
\hline & $0.92 \pm 0.27^{\star}$ & $2.36 \pm 0.53$ & $4.47 \pm 0.77^{\star}$ & $0.17 \pm 0.0$ & $0.20 \pm 0.05$ & $0.37 \pm 0.06^{\star}$ & $13.4 \pm 3.1$ \\
\hline \multicolumn{8}{|c|}{ Argentinian province (Subtropical) } \\
\hline Armases rubripes & $0.20 \pm 0.05$ & $0.50 \pm 0.08$ & $0.93 \pm 0.12^{*}$ & $0.14 \pm 0.02$ & $0.15 \pm 0.01$ & $0.16 \pm 0.02$ & 7.0 \\
\hline Neohelice granulata & $0.24 \pm 0.05$ & $0.47 \pm 0.09$ & $4.23 \pm 0.30^{*}$ & $0.37 \pm 0.02$ & $0.32 \pm 0.03$ & $0.37 \pm 0.01$ & 3.0 \\
\hline \multirow[t]{2}{*}{ Leptuca uruguayensis } & n.e. & $0.48 \pm 0.10$ & $5.81 \pm 0.11^{*}$ & $0.15 \pm 0.02$ & $0.16 \pm 0.00$ & $0.66 \pm 0.01^{*}$ & 5.8 \\
\hline & $0.22 \pm 0.02^{*}$ & $0.48 \pm 0.02$ & $3.66 \pm 1.44^{\star}$ & $0.22 \pm 0.06$ & $0.21 \pm 0.1$ & $0.40 \pm 0.15$ & $5.3 \pm 1.2$ \\
\hline \multicolumn{8}{|c|}{ Magellanic province (Sub-Antarctic) } \\
\hline Acanthocyclus albatrossis & n.e. & $0.20 \pm 0.03$ & $1.83 \pm 0.35^{\star}$ & n.e. & $0.30 \pm 0.00$ & $0.32 \pm 0.00$ & 2.1 \\
\hline \multirow[t]{2}{*}{ Halicarcinus planatus } & n.e. & $0.09 \pm 0.00$ & $0.14 \pm 0.01^{\star}$ & n.e. & $0.50 \pm 0.00$ & $0.37 \pm 0.03^{*}$ & 0.61 \\
\hline & & $0.15 \pm 0.05$ & $0.99 \pm 0.85$ & & $0.40 \pm 0.10$ & $0.35 \pm 0.03$ & $1.4 \pm 0.7$ \\
\hline
\end{tabular}

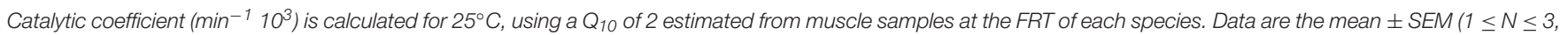

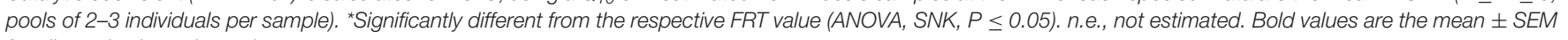
for all species in each province.

\section{Evolutionary and Comparative Patterns}

Zoogeographic province affected the evolution of muscle LDH activity at the FRT (pGLS ANOVA, $6.1 \leq F \leq 7.2, P \leq 0.03$, $\alpha=11.5)$. Tropical species showed a mean $V_{\max }(2.4 \pm 0.5$ $\left.\mathrm{U} \mathrm{mg}{ }^{-1}\right)$ greater than that of the subtropical $(0.5 \pm 0.0 \mathrm{U}$ $\left.\mathrm{mg}^{-1}\right)$ and sub-Antarctic $\left(0.2 \pm 0.1 \mathrm{U} \mathrm{mg}^{-1}\right)$ species (phyHolmBonferroni, $P \leq 0.05$ ) (Table 3). However, there was no effect of province on $\mathrm{V}_{\max }$ at either mean critical limit (pGLS ANOVA, $1.1 \leq F \leq 2.6, P \geq 0.06)$. Tropical $\left(0.9 \pm 0.3 \mathrm{U} \mathrm{mg}^{-1}\right)$ and subtropical representatives $\left(0.2 \pm 0.0 \mathrm{U} \mathrm{mg}^{-1}\right)$ showed similar mean $\mathrm{V}_{\max }$ 's at their mean $\mathrm{LL}_{50}$ 's (phyHolm-Bonferroni, $P \geq 0.14)$ and at their mean $\mathrm{UL}_{50}$ 's $\left(4.5 \pm 0.8 \mathrm{U} \mathrm{mg}^{-1}\right.$ and $3.7 \pm 1.4 \mathrm{U} \mathrm{mg}^{-1}$, respectively) (phyHolm-Bonferroni, $P \geq 0.14$ ).

The evolution of $\mathrm{K}_{\mathrm{m}}{ }^{\mathrm{Pyr}}$ was not affected by province under any thermal regime (pGLS ANOVA, $0.009 \leq F \leq 2.5, P \geq 0.14$ ) (Figure 6). Mean $\mathrm{K}_{\mathrm{m}}{ }^{\text {Pyr }}$ was $0.2 \mathrm{mM}$ at the mean FRT, $0.21 \mathrm{mM}$ at the mean $\mathrm{LL}_{50}$ and $0.37 \mathrm{mM}$ at the mean $\mathrm{UL}_{50}$. However, catalytic coefficient was associated with microhabitat temperature (pGLS ANOVA; $-0.62 \leq$ slope $\leq-0.64,5.4 \leq F \leq 8, P \leq 0.05$, $\Delta$ AIC $\leq 2, \alpha=22.9$ ), excluding the two outliers from the Magellanic province (Figure 6, insert).

\section{Phylogenetic Signal and Multi-Variate/Dimensional Patterns}

With regard to the upper critical limit $\left(\mathrm{UL}_{50}\right)$, all traits, i.e., $\mathrm{Q}_{\mathrm{O}}$, [Lac], $\mathrm{V}_{\max }$ and $\mathrm{K}_{\mathrm{m}}{ }^{\text {Pyr }}$, as well as $\mathrm{UL}_{50}$ itself, showed significant phylogenetic signal $(I>0.28, \mathrm{P}<0.05)$, thus their inter-specific variability exhibits a phylogenetic pattern. However, all other traits regarding exposure to $\mathrm{FRT}$ and $\mathrm{LL}_{50}$ were unrelated to phylogeny $(-0.22 \leq I \leq 0.19, P \geq 0.05)$.

Phylogenetic principal components analysis, grouping all traits, revealed that the first two dimensions accounted for $54.3 \%$ of the total physiological variance, specifically $38.1 \%$ for $\mathrm{PC}_{1}$ and $16.2 \%$ for $\mathrm{PC}_{2}$ (pPCA, Figure 7): $\mathrm{PC}_{1}$ is more related to the sub-Antarctic species while $\mathrm{PC}_{2}$ to the tropical/subtropical clade. This scenario is in agreement with the two adaptive peaks detected in the phylogeny: (i) at the root, and maintained in A. albatrossis and H. planatus; and (ii) a shift at the outset of the tropical and subtropical species (SURFACE analysis, Figure 7). Microhabitat temperature, $\mathrm{LL}_{50}$ and $\mathrm{UL}_{50}$ were the traits that most strongly correlated with the more relevant pPCA dimension $(R \geq 0.30)$, and also contributed most to the adaptive peaks $(-14<$ AICc $<-8)$ as evaluated using SURFACE.

\section{DISCUSSION}

We found that tropical and subtropical intertidal crab species showed similar subcellular and organismic responses to acute thermal stress, differing from their sub-Antarctic relatives. Oxygen consumption $\left(\mathrm{QO}_{2}\right)$ and hemolymph lactate ([Lac]) increased with increasing temperature in all species from the three zoogeographical provinces, revealing an apparent tradeoff with the evolution of upper critical thermal limit $\left(\mathrm{UL}_{50}\right)$. While maximum LDH activity $\left(\mathrm{V}_{\max }\right)$ also increased with temperature, $\mathrm{K}_{\mathrm{m}}{ }^{\mathrm{Pyr}}$ tended to remain constant, whereas the catalytic coefficient is driven by micro-habitat temperature in 


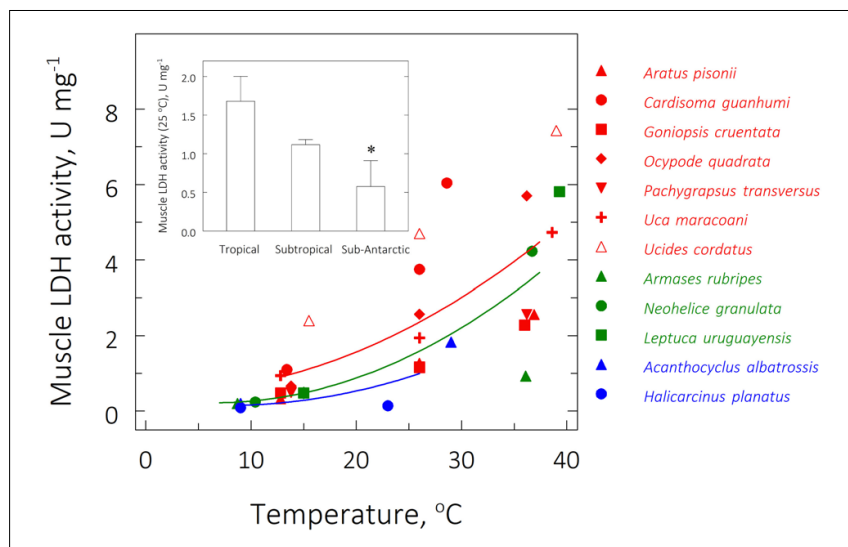

FIGURE 5 | Effect of direct transfer of tropical (red), subtropical (green), and sub-Antarctic (blue) crab species on muscle lactate dehydrogenase (LDH) activity $\left(\mathrm{V}_{\max }, \mathrm{U} \mathrm{mg^{-1 }}\right)$ after $6 \mathrm{~h}$ exposure to their respective upper and lower critical thermal limits from their corresponding field reference temperatures (FRT) of 26,15 , and $9^{\circ} \mathrm{C}$. Data are mean values $(2 \leq N \leq 3$, pools of 3 individuals each) and were adjusted to a second degree polynomial curve. $V_{\max }$ was measured continuously in duplicate aliquots at the same experimental temperatures. Activities could not be measured for the sub-Antarctic species at their lower critical thermal limits. Insert: Mean ( \pm SEM) muscle $\mathrm{LDH}$ activity at $25^{\circ} \mathrm{C}$ for all species from each province ( $2 \leq N \leq 3$, pools of 3 individuals each); muscle samples taken at the FRT of each species. *Significantly different from tropical crab species (phyHolm-Bonferroni, $P \leq 0.05$ ).

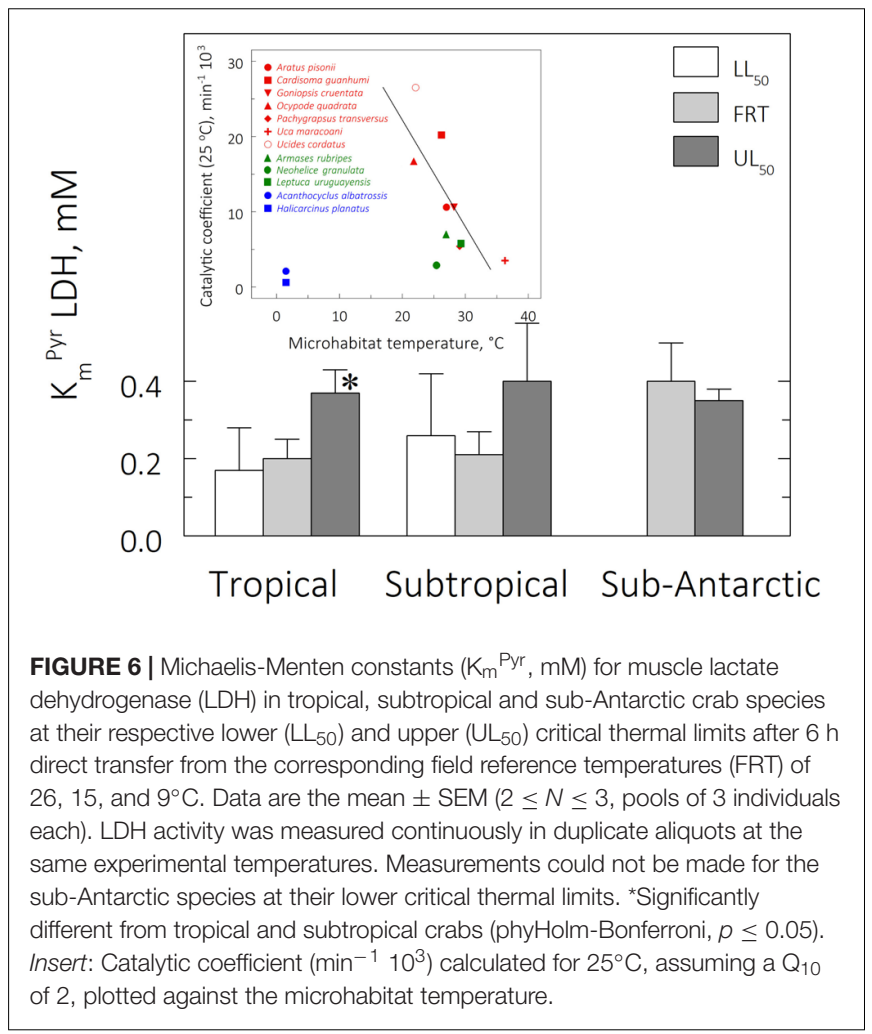

most cases. Interestingly, all physiological traits at the $\mathrm{UL}_{50}$ have evolved in a phylogenetic fashion, while the others linked to $\mathrm{LL}_{50}$ and FRT were more plastic. Overall metabolic evolution at

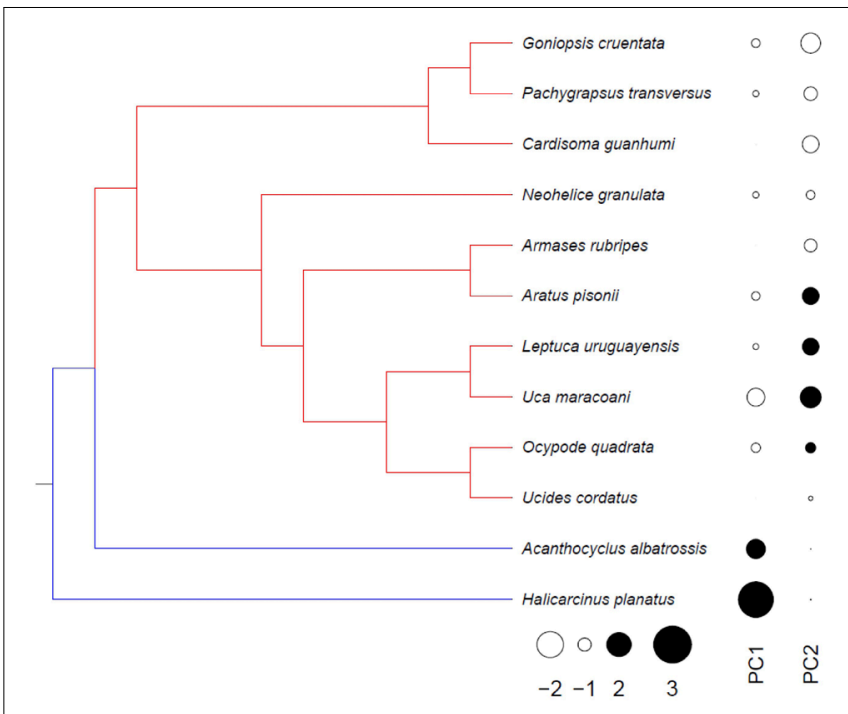

FIGURE 7 | Overall physiological evolution of thermal tolerance, grouping systemic and kinetic traits in intertidal crabs distributed from northern Brazil to southern Patagonia, mapped onto a phylogeny modified from Faria et al. (2017). Different colors represent adaptive peaks identified using the SURFACE method: the first optimum (blue) was detected for the sub-Antarctic species while the second (red) was found in the tropical and subtropical representatives. Using a phylogenetic PCA, the first two dimensions accounted for $54.3 \%$ of total physiological variance, specifically $38.1 \%$ for $\mathrm{PC}_{1}$ and $16.2 \%$ for $\mathrm{PC}_{2}$. The scores of both dimensions follow the same phylogenetic pattern as the adaptive peaks. Microhabitat temperature, $L_{50}$ and $U_{50}$ were the most important parameters in both analyses $(R \geq 0.30$ for pPCA, $-14<$ AIC $<-8$ for SURFACE).

both critical limits has taken place by two independent adaptive pathways in the sub-Antarctic lineages, however one adaptive peak has been inherited by the northernmost species. These physiological patterns and evolutionary history appear to reflect the species' ability to function at higher temperatures, together with a lesser capacity to confront lower temperatures, since the crabs were likely acclimatized to the southern summer. The discussion that follows should be considered in this light.

\section{Systemic Metabolism}

The systemic metabolism complied with the paradigm that higher temperatures lead to greater energy demands through increased $\mathrm{QO}_{2}$ and $[\mathrm{Lac}]$. The highest values for these parameters were seen at the $\mathrm{UL}_{50}$ while the lowest values occurred at the $\mathrm{LL}_{50}$, both compared to the FRT. At the FRT, the tropical crab species exhibited a mean $\mathrm{QO}_{2}$ 6-fold greater than the mean value for the subtropical crabs, and 3 -fold greater than the sub-Antarctic representatives. The same phenomenon has occurred in the Echinodermata, Annelida, other Crustacea, and Mollusca: warmer water species show higher rates of oxygen consumption than do colder water species when measured at their respective usual environmental temperatures (Fox, 1936), reaching up to 10 -fold greater in crustaceans from tropical waters than in polar species (Scholander et al., 1953). Further, the subAntarctic crab species showed a 2-fold higher $\mathrm{QO}_{2}$ at the FRT of $9^{\circ} \mathrm{C}$ than did the subtropical crabs at the FRT of $15^{\circ} \mathrm{C}$, 
which reveals temperature compensation of aerobic metabolism in cold regions, an adaptive peak probably maintained by strong stabilizing selection as revealed by the higher $\alpha$-value.

The evolution of temperature compensation of aerobic capacity as observed here may result from the differential regulation of hemolymph $\mathrm{Mg}^{2+}$ as seen in some decapod crustaceans (Frederich et al., 2000; Wittmann et al., 2010, 2012) or may be due to selective pressure on cellular energy demand, as demonstrated in fish (Peck et al., 2002; Pörtner, 2002; Morley et al., 2009). Hemolymph $\mathrm{Mg}^{2+}$ hypo-regulation is associated with higher activity levels in decapods from low temperatures since higher $\mathrm{Mg}^{2+}$ concentrations diminish activity by inhibiting $\mathrm{Ca}^{2+}$ influx across neuronal membranes, slowing down neuromuscular transmission and decreasing muscle contraction (Parnas et al., 1994; Dunn and Mercier, 2003). Elevated activity levels in decapods from naturally or experimentally cold temperatures are due to fairly high heart rates, ventilation frequencies and oxygen consumption, as a consequence of lower $\mathrm{Mg}^{2+}$ levels (Frederich and Pörtner, 2000). Increased mitochondrial densities also contribute to elevated aerobic metabolism in fish acclimated to cold temperatures revealing ultrastructural adjustments (Johnston and Maitland, 1980; Tyler and Sidell, 1984). Both hypotheses, in combination or independently, may explain the higher $\mathrm{QO}_{2}$ values seen in the sub-Antarctic species.

With regard to phylogenetic signal for oxygen consumption, closely related species do not show similar $\mathrm{QO}_{2}$ 's at the FRT and $\mathrm{LL}_{50}$, which is also supported by the effect of zoogeographical province on $\mathrm{QO}_{2}$ under both thermal regimes together with a significant effect of selection strength $(17 \leq \alpha \leq 20)$. Given the physical dependence of $\mathrm{QO}_{2}$ on the kinetic energy of the molecules, this scenario suggests adaptive evolution strongly driven by thermal regime, regardless of the phylogenetic position of each species. To illustrate, the fiddler crabs sampled, i.e., the tropical species $U$. maracoani and the subtropical species $L$. uruguayensis, although closely related, exhibit distinct $\mathrm{QO}_{2}$ 's under their natural temperature conditions and on cold challenge. Conversely, aerobic metabolism at the $\mathrm{UL}_{50}$ is similar among closely related species, also reinforced by the absence of a province effect, signifying that inter-specific variability in $\mathrm{QO}_{2}$ at higher temperatures is constrained by shared inheritance, regardless of a significant effect of thermal regime. The maximum aerobic capacities at higher temperature challenge vary among species in a phylogenetic fashion.

With respect to anaerobic metabolism, mean [Lac] in the subtropical crab species did not vary as a function of their respective FRT and $\mathrm{LL}_{50}$, while the tropical and sub-Antarctic crabs showed a reduction of $\approx 50$ and $70 \%$, respectively, in mean [Lac] at the mean $\mathrm{LL}_{50}$ compared to FRT. Since the subtropical species encounter a eurythermic environment owing to the mixing of warm water from the Brazilian Current with colder water from the Malvinas Current (Boschi, 2000a), their stable anaerobic metabolism suggests the capability for cold acclimatization and energy production even during rapid temperature changes such as might occur during exposure at low tide. In contrast, the tropical and sub-Antarctic crabs hail from more stenothermic provinces, dominated respectively by the
South Equatorial Current and by sub-Antarctic waters (Boschi, 2000a; Thurman et al., 2013), suggesting that rapid cooling effects are more pervasive and more able to reduce anaerobic energy production. However, species from all three zoogeographical provinces showed an increase in mean [Lac] during exposure at their $\mathrm{UL}_{50}$ compared to the FRT. Mean [Lac] was 1.4- and 1.8 -fold higher at the mean $\mathrm{UL}_{50}$ of $\approx 39^{\circ} \mathrm{C}$ for the tropical and subtropical species, respectively, but 17 -fold higher at the mean $\mathrm{UL}_{50}$ of $26^{\circ} \mathrm{C}$ for the sub-Antarctic species, revealing a stronger effect of higher temperatures in species acclimatized to a colder province. The lack of mobilization of lactate at the lower critical limits is possibly due to a lower cellular energy demand, which is compatible with the lower kinetic energy of the molecules.

The high [Lac] at the upper critical temperatures indicates recruitment of anaerobiosis owing to high tissue energy demand, while the high $\mathrm{QO}_{2}$ 's suggest some cardiorespiratory capability in supplying tissues with oxygen. For example, the spider crab Maja squinado shows changes in [Lac] in some tissues in tandem with a reduction in aerobic capacity. $\operatorname{High}\left(33^{\circ} \mathrm{C}\right)$ and low $\left(0^{\circ} \mathrm{C}\right)$ temperatures provoke decoupling between $\mathrm{O}_{2}$ supply and demand, since mitochondrial $\mathrm{O}_{2}$ consumption is consistent with oxygen delivery by the cardiorespiratory system (Frederich and Pörtner, 2000). Further, in decapod crustaceans subjected to hypoxia or exercise, lactate affects hemocyanin affinity for oxygen, increasing oxygen extraction by the gills and transport by the hemolymph to the tissues as seen in the brachyuran crabs Cancer, Carcinus, and Hyas (Truchot, 1980; Morris and Bridges, 1989), Homarus lobsters (Nies et al., 1992) and Macrobrachium shrimps (Ern et al., 2013).

Since aerobic and anaerobic metabolism are both linked to the energy supply of a biological system (see Pörtner et al., 2017), the lower mean $\mathrm{UL}_{50}$ for the sub-Antarctic crabs $\left(\approx 26^{\circ} \mathrm{C}\right)$ compared to the mean $\mathrm{UL}_{50}$ for the tropical and subtropical species $\left(\approx 37^{\circ} \mathrm{C}\right)$ may reflect a mismatch between aerobic and anaerobic energy production at the upper critical limits. In fact, under high thermal challenge, the sub-Antarctic species have evolved a lower aerobic metabolism ( 0.4 -fold), albeit circumvented by an augmented anaerobic capacity (9.1-fold) when compared to the mean values for the tropical and subtropical species (Figure 4). Since aerobic capacity ensures higher ATP production (potentially up to 38 ATP molecules per glucose molecule) than does anaerobic metabolism (only 2 ATP molecules), the lower energy budget available to the sub-Antarctic species could impair overall cellular activities such as anti-oxidant defenses and heat-shock responses, reducing thermal tolerance. The acute stress encountered at the upper critical temperatures constrains aerobic capacity and shifts the energy generating system to a predominantly anaerobic metabolism in crabs from colder climates, suggesting an evolutionary metabolic trade-off during thermal niche diversification.

\section{LDH Kinetics}

For each zoogeographical province, mean $\mathrm{V}_{\max }$ tends to become reduced at the $\mathrm{LL}_{50}$ and to increase at the $\mathrm{UL}_{50}$, both compared to the respective FRT. Interestingly, at the fixed temperature of $25^{\circ} \mathrm{C}$, there was an effect of zoogeographical province: mean $\mathrm{V}_{\max }$ for the sub-Antarctic species was 3-fold lower than that 
for tropical species. This tendency for lower activities at the same temperature for species from colder regions contrasts with previous data for tropical/subtropical and Antarctic fish (Kawall et al., 2002) that show thermal compensation of LDH specific activity. In this case, brain LDH activity was up to 2.5-fold higher in the Antarctic species, while muscle LDH activities were similar between the two thermal groups, both measured at the same temperature of $10^{\circ} \mathrm{C}$ (Kawall et al., 2002).

The absence of thermal compensation in LDH activity in the intertidal, neotropical crabs evaluated here corroborates findings for another intertidal decapod clade distributed from Northern to Central America, anomuran crabs Petrolisthes. No effect of maximum habitat temperature was seen on the evolution of LDH thermal stability in 22 congeneric species sampled over a $\approx 35^{\circ}$ range of latitude, suggesting that the diversity of $\mathrm{LDH}$ stabilities also is not adaptive (Stillman and Somero, 2001). Further, similar stabilities at maximum temperatures for some sibling Petrolisthes groups were suggested, which is reinforced here for neotropical crabs, owing to the phylogenetic signal seen for $\mathrm{V}_{\max }$ at $\mathrm{UL}_{50}$. Although maximum and critical temperatures, respectively, do not constitute a selective pressure on the evolution of $\mathrm{LDH}$ stability (anomurans) and activity (brachyurans), the interspecific variability in these mechanistic bases demonstrates the importance of ancestral inertia in the evolutionary history of different intertidal decapod lineages.

While $\mathrm{V}_{\max }$ does not suggest $\mathrm{LDH}$ thermal compensation when comparing activities at the same temperature, the catalytic coefficient (also at $25^{\circ} \mathrm{C}$ ) correlated negatively with micro-habitat temperatures (MHT). Species sampled from higher MHT tend to have lower catalytic coefficients and vice-versa (except for the sub-Antarctic species $A$. albatrossis and $H$. planatus). In fact, the lower MHT values $\left(21-26^{\circ} \mathrm{C}\right)$ show a mean catalytic coefficient 2.5-fold higher than the mean value for the species from warmer habitats $\left(28-36^{\circ} \mathrm{C}\right)$, which means that species from colder MHT's show more flexible $\mathrm{LDH}$ molecules, while conversely, those from warmer habitats show more rigid enzymes. In contrast, mean $\mathrm{K}_{\mathrm{m}}$ Pyr tends to be constant $(\approx 0.27 \mathrm{mM})$, reflecting retention of $\mathrm{LDH}$ affinity for pyruvate and, consequently, its binding efficiency.

The temperature compensation of LDH activity has evolved through the transformation of catalytic efficiency, which is in agreement with maintenance of binding capacity for pyruvate (see Hochachka and Somero, 2002). Such a biochemical tradeoff has been documented for several fish species from various thermal niches, such as Sphyraena barracudas (Holland et al., 1997), Chromis Pacific fish (Johns and Somero, 2004) and four families of Antarctic notothenioids (Fields and Somero, 1998). The maintenance of the LDH binding property demonstrates conservation of the catalytic site. Variability in enzyme efficiency results from alterations to the amino acid sequence in regions that undergo conformational changes during formation of the enzyme-substrate complex (see Hochachka and Somero, 2002). The reasons why $\mathrm{LDH}$ in tropical species has lost its affinity (higher $\mathrm{K}_{\mathrm{m}}{ }^{\mathrm{Pyr}}$ ) during exposure at $\mathrm{UL}_{50}$, and why sub-Antarctic crabs have not retained a higher catalytic efficiency at their natural MHT, remain conjectural and require investigation at the molecular level.
Overall physiological evolution, when considered simultaneously for all systemic and kinetic traits, including MHT and both critical limits, consists of two steps. The first took place at the outset of the present crab phylogeny, and the second at the outset of the tropical + subtropical lineage, owing to the shift between the two main dimensions, $\mathrm{PC}_{1}$ for the sub-Antarctic species and $\mathrm{PC}_{2}$ for the tropical and subtropical crabs (Figure 7). Interestingly, these findings are in agreement with the two adaptive peaks detected in this crab phylogeny: one at the root, and maintained in $A$. albatrossis and $H$. planatus, and another at the outset of the tropical and subtropical species. However, since the subAntarctic $A$. albatrossis and $H$. planatus are a paraphyletic grouping, also belonging to different eubrachyuran families (Bellidae and Hymenosomatidae, respectively, see Faria et al., 2017), the adaptive peak revealed here should be interpreted as the result of adaptive convergence. The adaptive peaks detected using SURFACE are also in concert with most evolutionary associations detected using PGLS since they were better adjusted by the $\mathrm{O}-\mathrm{U}$ model, with higher selection strengths that limit minimum and maximum physiological capabilities. The reason why the most important traits that contribute to this macroevolutionary landscape are the thermal niche, and the upper and lower critical thermal limits, may depend on their underlying biological organization, since such traits integrate lower hierarchical levels, including lesser physiological differences, following the synergistic principle of the "part-whole" relationship.

In summary, the metabolic physiology of crabs living at the edge of their thermal windows accompanies the asymmetry of their critical limits. The extension of life to higher temperatures depends on a putative trade-off between the evolution of aerobic and anaerobic metabolism with respect to energy supply, while temperature compensation of kinetic performance is driven by thermal habitat, as revealed by the LDH affinity/efficiency equilibrium. In fact, shared inheritance and the thermal environment both affect the overall physiological history of these intertidal crabs, revealing that certain evolutionary transformations have arisen both in warmer and in colder climes, particularly at higher levels of biological organization and phylogenetic diversity.

\section{DATA AVAILABILITY STATEMENT}

The datasets generated for this study are available on request to the corresponding author.

\section{ETHICS STATEMENT}

Crab sampling in Brazil was authorized by the Ministry for the Environment (MMA/ICMBio permit \#29594-8 to JM), and in Argentina by the Ministry for the Environment, Sustainable Development and Climate Change of Tierra del Fuego (permit \#0116/2014 to MR). 


\section{AUTHOR CONTRIBUTIONS}

SF and JM contributed to the conceptualization, the data curation, the project administration, the funding acquisition, and the visualization. SF, ML, AZ, FT, MR, AB, and JM contributed to the methodology, writing, review, and the editing. SF contributed to the software, writing, and the initial draft. SF, ML, and JM contributed to the formal analysis. SF, ML, FT, MT, and JM contributed to the investigation. SF, AB, FT, MR, and JM contributed to the resources. JM contributed to the supervision.

\section{FUNDING}

This work was supported by the Fundação de Amparo à Pesquisa do Estado de São Paulo (FAPESP scholarship \#2011/088520 to SF, and grants \#2011/22537-0 and \#2020/04135-1 to JM), the Conselho Nacional de Desenvolvimento Científico e Tecnológico (CNPq \#450320/2010-3 and \#300662/20092 to JM) and the Coordenação de Aperfeiçoamento de

\section{REFERENCES}

Abouheif, E. (1999). A method for testing the assumption of phylogenetic independence in comparative data. Evol. Ecol. Res. 1, 895-909.

Balech, E. (1954). División zoogeográfica del litoral sudamericano. Rev. Biol. Mar. Dep. Oceanol. Univ. Chile 4, 184-195.

Bergmeyer, H. U., and Bernt, E. (1974). "“L-lactate analyses", in Methods of Enzymatic Analysis, 2nd Edn, Vol. II, ed. H. U. Bergmeyer (New York: Academic Press), 574-579.

Boschi, E. E. (2000a). Species of decapod crustaceans and their distribution in the American marine zoogeographic provinces. Rev. Invest. Des. Pesq. 13, 7-136.

Boschi, E. E. (2000b). Biodiversity of marine decapod brachyurans of the Americas. J. Crust. Biol. 20, 337-342. doi: 10.1163/1937240x-90000036

Boschi, E. E., and Gavio, M. A. (2005). On the distribution of decapod crustaceans from the Magellan Biogeographic Province and the Antarctic region. Sci. Mar. 69, 195-200. doi: 10.3989/scimar.2005.69s2195

Briggs, J. C. (1974). Marine Zoogeography. New York, NY: Mc-Graw-Hill.

Cannon, W. B. (1929). The wisdom of the body. Physiol. Rev. 9, 399-431.

Carcelles, A. R., and Williamson, S. I. (1951). Catalogo de los moluscos de la provincia magallanica. Revta. Lnst. Nac. Invest. Cienc. Nat. 2, 255-383.

Cooke, A. H. (1895). "Mollusca," in The Cambridge Natural History, eds S. F. Harmer and A. E. Shipley (London: MacMillan).

Cowles, R. B., and Bogert, C. M. (1944). A preliminary study of the thermal requirements of desert reptiles. Bull. Am. Mus. Nat. Hist. 83, 265-296.

Diniz-Filho, J. A. F. (2001). Phylogenetic autocorrelation under distinct evolutionary processes. Evolution 55, 1104-1109. doi: 10.1111/j.0014-3820. 2001.tb00630.x

Dong, Y., Miller, L. P., Sanders, J. G., and Somero, G. N. (2008). Heat-shock protein 70 (Hsp70) expression in four limpets of the genus Lottia: interspecific variation in constitutive and inducible synthesis correlates with in situ exposure to heat stress. Biol. Bull. 215, 173-181. doi: 10.2307/25470698

Dunn, C. R., Wilks, H. M., Halsall, D. J., Atkinson, T., Clarke, A. R., Muirhead, H., et al. (1991). Design and synthesis of new enzymes based on the lactate dehydrogenase framework. Phil. Trans. R. Soc. B 332, 177-184. doi: 10.1098/ rstb.1991.0047

Dunn, T. W., and Mercier, A. J. (2003). Synaptic modulation by a neuropeptide depends on temperature and extracellular calcium. J. Neurophysiol. 89, 18071814. doi: 10.1152/jn.00710.2002

Ern, R., Huong, D. T. T., Nguyen, V. C., Wang, T., and Bayley, M. (2013). Effects of salinity on standard metabolic rate and critical oxygen tension in the giant freshwater prawn (Macrobrachium rosenbergii). Aquat. Res. 44, 1259-1265. doi: 10.1111/j.1365-2109.2012.03129.x
Pessoal de Nível Superior (CAPES 33002029031P8, finance code 001 , to JM). SF was a post-doctoral investigator (FAPESP \#2018/17252-6).

\section{ACKNOWLEDGMENTS}

We are grateful to P. Barreto, R. Faleiros, M. Sotelano, O. Florentin, R. Lorenzo, and R. Padilha for assisting with fieldwork or preparing dry ice. We also thank Drs. Luiz Carlos Alves and Fábio Brayner for generously offering their facilities in Pernambuco, Drs. Douglas Masui, Eduardo Oliveira and Luana Meleiro for assistance with kinetic assays, and Dr. Wilfried Klein for helping set up the FoxBox system. SF is especially thankful to Dr. Rosa Furriel for supervising the biochemical kinetic assays and for her rare mixture of humanity and science. This investigation is part of a Ph.D. thesis submitted by SF to the Graduate Program in Comparative Biology, Departamento de Biologia, FFCLRP, Universidade de São Paulo.

Faria, S. C., Faleiros, R. O., Brayner, F. A., Alves, L. C., Bianchini, A., Romero, C., et al. (2017). Macroevolution of thermal tolerance in intertidal crabs from Neotropical provinces: a phylogenetic comparative evaluation of critical limits. Ecol. Evol. 7, 3167-3176. doi: 10.1002/ece3.2741

Felsenstein, J. (1973). Maximum likelihood and minimum-steps methods for estimating evolutionary trees from data on discrete characters. Syst. Biol. 22, 240-249. doi: 10.1093/sysbio/22.3.240

Felsenstein, J. (1981). Evolutionary trees from DNA sequences: a maximum likelihood approach. J. Mol. Evol. 17, 368-376. doi: 10.1007/bf01734359

Fields, P. A. (2001). Protein function at thermal extremes: balancing stability and flexibility. Comp. Biochem. Physiol. 129, 417-431. doi: 10.1016/s1095-6433(00) 00359-7

Fields, P. A., and Somero, G. N. (1998). Hot spots in cold adaptation: localized increases in conformational flexibility in lactate dehydrogenase $\mathrm{A}_{4}$ orthologs of Antarctic notothenioid fishes. Proc. Natl. Acad. Sci. 95, 11476-11481. doi: 10.1073/pnas.95.19.11476

Fox, H. M. (1936). The activity and metabolism of poikilothermal animals in different latitudes. Proc. Zool. Soc. London. 1936, 945-955. doi: 10.1111/j.14697998.1936.tb06295.x

Frederich, M., and Pörtner, H. O. (2000). Oxygen limitation of thermal tolerance defined by cardiac and ventilatory performance in the spider crab Maja squinado. Am. J. Physiol. 279, 1531-1538.

Frederich, M., Sartoris, F. J., Arntz, W. E., and Pörtner, H. O. (2000). Haemolymph $\mathrm{Mg}^{2+}$ regulation in decapod crustaceans: physiological correlates and ecological consequences in polar areas. J. Exp. Biol. 203, 1383-1393.

Garland, T. Jr., and Ives, I. R. (2000). Using the past to predict the present: confidence intervals for regression equations in phylogenetic comparative methods. Am. Nat. 155, 346-364. doi: 10.1086/303327

Giomi, F., Fusi, M., Barausse, A., Mostert, B., Pörtner, H. O., and Cannicci, S. (2014). Improved heat tolerance in air drives the recurrent evolution of air-breathing. Proc. R. Soc. Lond. B. 281, 20132927. doi: 10.1098/rspb.2013.2927

Giomi, F., and Pörtner, H. O. (2013). A role for haemolymph oxygen capacity in heat tolerance of eurythermal crabs. Front. Physiol 4:110. doi: 10.3389/fphys. 2013.00110

Gittleman, J. L., and Kot, M. (1990). Adaptation: statistics and a null model for estimating phylogenetic effects. Syst. Zool. 39, 227-241.

Grafen, A. (1989). The phylogenetic regression. Philos. Trans. Roy. Soc. 326, $119-157$.

Henry, R. P., Booth, C. E., Lallier, F. H., and Walsh, P. J. (1994). Post-exercise lactate production and metabolism in three species of aquatic and terrestrial decapod crustaceans. J. Exp. Biol. 186, 215-234. 
Hochachka, P. W., and Somero, G. N. (2002). Biochemical Adaptation: Mechanism and Process in Physiological Evolution. New York, NY: Oxford University Press.

Holland, L. Z., McFall-Ngai, M., and Somero, G. N. (1997). Evolution of lactate dehydrogenase-A homologues of barracuda fishes (genus Sphyraena) from different thermal environments: differences in kinetic properties and thermal stability are due to amino acid substitutions outside the active site. Biochemistry 36, 3207-3215. doi: 10.1021/bi962664k

Ingram, T., and Mahler, D. L. (2013). SURFACE: detecting convergent evolution from comparative data by fitting Ornstein-Uhlenbeck models with stepwise Akaike Information Criterion. Methods Ecol Evol 4, 416-425. doi: 10.1111/ 2041-210x.12034

Johns, G. C., and Somero, G. N. (2004). Evolutionary convergence in adaptation of proteins to temperature: $\mathrm{A}_{4}$-lactate dehydrogenases of Pacific damselfishes (Chromis spp.). Mol. Biol. Evol. 21, 314-320. doi: 10.1093/molbev/ msh021

Johnston, I. A., and Maitland, B. (1980). Temperature acclimation in crucian carp (Carassius carassius L): morphometric analysis of muscle fibre ultrastructure. J. Fish. Biol. 17, 113-125. doi: 10.1111/j.1095-8649.1980.tb 02746.x

Jombart, T., Balloux, F., and Dray, S. (2010). Adephylo: new tools for investigating the phylogenetic signal in biological traits. Bioinformatics 26, 1907-1909. doi: 10.1093/bioinformatics/btq292

Jost, J. A., Podolski, S. M., and Frederich, M. (2012). Enhancing thermal tolerance by eliminating the pejus range: a comparative study with three decapod crustaceans. Mar. Ecol. Prog. Ser. 444, 263-274. doi: 10.3354/meps 09379

Kawall, H., Torres, J., Sidell, B., and Somero, G. (2002). Metabolic cold adaptation in Antarctic fishes: evidence from enzymatic activities of brain. Mar. Biol. 140, 279-286. doi: 10.1007/s002270100695

Lavin, S. R., Karasov, W. H., Ives, A. R., Middleton, K. M., and Garland, T. Jr. (2008). Morphometrics of the avian small intestine, compared with nonflying mammals: a phylogenetic perspective. Physiol. Biochem. Zool. 81, 526-550. doi: $10.1086 / 590395$

Leone, F. A., Baranauskas, J. A., Furriel, R. P. M., and Borin, I. A. (2005). SigrafW: an easy-to-use program for fitting enzyme kinetic data. Biochem. Mol. Biol. Educ. 33, 399-403. doi: 10.1002/bmb.2005.49403306399

Mantelatto, F. L., Pardo, L. M., Pileggi, L. G., and Felder, D. L. (2009a). Taxonomic re-examination of the hermit crab species Pagurus forceps and Pagurus comptus (Decapoda: Paguridae) by molecular analysis. Zootaxa 2133, 20-32. doi: 10. 11646/zootaxa.2133.1.2

Mantelatto, F. L., Robles, R., Schubart, C. D., and Felder, D. L. (2009b). "Molecular phylogeny of the genus Cronius Stimpson, 1860, with reassignment of C. tumidulus and several American species of Portunus to the genus Achelous De Haan, 1833 (Brachyura: Portunidae)," in Crustacean issues: Decapod crustacean phylogenetics, eds J. M. Martin, K. A. Crandall, and D. L. Felder (Boca Raton: Taylor \& Francis/CRC Press), 537-551.

Morley, S. A., Lurman, G. L., Skepper, J. N., Pörtner, H. O., and Peck, L. S. (2009). Thermal plasticity of mitochondria: A latitudinal comparison between Southern Ocean molluscs. Comp. Biochem. Physiol. 152, 423-430. doi: 10.1016/ j.cbpa.2008.11.015

Morris, S., and Bridges, C. R. (1989). Interactive effects of temperature and L-lactate on the binding of oxygen by the hemocyanin of two arctic boreal crabs, Hyas araneus and Hyas coarctatus. Physiol. Zool. 62, 62-82. doi: 10.1086/physzool.62. 1.30159998

National Oceanic and Atmospheric Administration [NOAA], and U. S. Department of Commerce (2019). Satellite Data Products for Understanding and Managing Our Oceans and coasts. Avaliable at: https://coastwatch.noaa.gov/ cw/index.html (accessed July 2019).

Nies, A., Zeis, B., Bridges, C. R., and Grieshaber, M. K. (1992). Allosteric modulation of haemocyanin oxygen-affinity by lactate and urate in the lobster Homarus vulgaris: II. Characterization of specific effector binding sites. J. Exp. Biol. 168, 111-124.

Northrop, D. B. (1998). On the meaning of $\mathrm{Km}$ and $\mathrm{V} / \mathrm{K}$ in enzyme kinetics. J. Chem. Educ. 75:1153. doi: 10.1021/ed075p1153

Paradis, E., Claude, J., and Strimmer, K. (2004). Ape: analyses of phylogenetics and evolution in R language. Bioinformatics 20, 289-290. doi: 10.1093/ bioinformatics/btg 412
Parnas, H., Parnas, I., Ravin, R., and Yudelevitch, B. (1994). Glutamate and $\mathrm{N}$-methyl-D-aspartate affect release from crayfish axon terminals in a voltagedependent manner. Proc. Nat. Acad. Sci. U.S.A. 91, 11586-11590. doi: 10.1073/ pnas.91.24.11586

Pavoine, S., Ollier, S., Pontier, D., and Chessel, D. (2008). Testing for phylogenetic signal in phenotypic traits: new matrices of phylogenetic proximities. Theor. Popul. Biol. 73, 79-91. doi: 10.1016/j.tpb.2007.10.001

Peck, L. S., Pörtner, H. O., and Hardewig, I. (2002). Metabolic demand, oxygen supply and critical temperatures in the Antarctic bivalve Laternula elliptica. Physiol. Biochem. Zool. 75, 123-133. doi: 10.1086/340990

Pileggi, L. G., and Mantelatto, F. L. (2010). Molecular phylogeny of the freshwater prawn genus Macrobrachium (Decapoda, Palaemonidae), with emphasis on the relationships among selected American species. Invertebr. Syst. 24, 194-208.

Pinheiro, J., Bates, D., DebRoy, S., and R Core Team (2015). nlme: Linear and Nonlinear Mixed Effects Models. R Package Version 3. 1-137.

Pörtner, H. O. (2002). Climate variations and the physiological basis of temperature dependent biogeography: systemic to molecular hierarchy of thermal tolerance in animals. Comp. Biochem. Physiol. 132, 739-761. doi: 10.1016/s1095-6433(02) 00045-4

Pörtner, H. O., Bock, C., and Mark, F. C. (2017). Oxygen-and capacity-limited thermal tolerance: bridging ecology and physiology. J. Exp. Biol. 220, 26852696. doi: $10.1242 /$ jeb. 134585

Pörtner, H. O., and Gutt, J. (2016). Impacts of climate variability and change on (marine) animals: physiological underpinnings and evolutionary consequences. Integr. Comp. Biol. 56, 31-44. doi: 10.1093/icb/icw019

R Development Core Team (2019). R: A Language and Environment for Statistical Computing. Vienna: R Foundation for Statistical Computing. doi: 10.1093/icb/ icw019

Read, S. M., and Northcote, D. H. (1981). Minimization of variation in the response to different protein of the Coomassie blue $\mathrm{G}$ dye-binding assay for protein. Anal. Biochem. 116, 53-64. doi: 10.1016/0003-2697(81)90321-3

Recordati, G., and Bellini, T. G. (2004). A definition of internal constancy and homeostasis in the context of non-equilibrium thermodynamics. Exp. Physiol. 89, 27-38. doi: 10.1113/expphysiol.2003.002633

Revell, L. J. (2010). Phylogenetic signal and linear regression on species data. Methods Eco.l Evol. 1, 319-329. doi: 10.1111/j.2041-210x.2010.00044.x

Revell, L. J. (2012). Phytools: an R package for phylogenetic comparative biology (and other things). Method Ecol. Evol. 3, 217-223. doi: 10.1111/j.2041-210x. 2011.00169.x

Santos, E. A., and Keller, R. (1993). Effect of exposure to atmospheric air on blood glucose and lactate concentrations in two crustacean species: a role of the crustacean hyperglycemic hormone (CHH). Comp. Biochem. Physiol. 106, 343-347. doi: 10.1016/0300-9629(93)90523-7

Scholander, P. F., Flagg, W., Walters, V., and Irving, L. (1953). Climatic adaptation in arctic and tropical poikilotherms. Physiol. Zool. 26, 67-92. doi: 10.1086/ physzool.26.1.30152151

Schubart, C. D., Cuesta, J. A., Diesel, R., and Felder, D. L. (2000). Molecular phylogeny, taxonomy, and evolution of nonmarine lineages within the American grapsoid crabs (Crustacea: Brachyura). Mol. Phylogenet. Evol. 15, 179-190. doi: 10.1006/mpev.1999.0754

Segel, I. H. (1976). Enzymes. Biochemical Calculations. New York, NY: John Wiley \& Sons, 208-323.

Somero, G. N. (2003). Protein adaptations to temperature and pressure: complementary roles of adaptive changes in amino acid sequence and internal milieu. Comp. Biochem. Physiol. 136, 577-591. doi: 10.1016/s1096-4959(03) 00215-x

Somero, G. N. (2004). Adaptation of enzymes to temperature: searching for basic 'strategies'. Comp. Biochem. Physiol. 139, 321-333. doi: 10.1016/j.cbpc.2004. 05.003

Somero, G. N. (2010). The physiology of climate change: how potentials for acclimatization and genetic adaptation will determine 'winners' and 'losers.'. J. Exp. Biol. 213, 912-920. doi: 10.1242/jeb.037473

Stamatakis, A. (2006). RAxML-VI-HPC: maximum likelihood-based phylogenetic analyses with thousands of taxa and mixed models. Bioinformatics 22, 26882690. doi: 10.1093/bioinformatics/btl446

Stamatakis, A., Hoover, P., and Rougemont, J. (2008). A rapid bootstrap algorithm for the RAxML web servers. Syst. Biol. 57, 758-771. doi: 10.1080/ 10635150802429642 
Steffensen, J. F. (1989). Some errors in respirometry of aquatic breathers: how to avoid and correct them. Fish. Physiol. Biochem. 6, 49-59. doi: 10.1007/ bf02995809

Stevens, M. M., Jackson, S., Bester, S. A., Terblanche, J. S., and Chown, S. L. (2010). Oxygen limitation and thermal tolerance in two terrestrial arthropod species. J. Exp. Biol. 213, 2209-2218. doi: 10.1242/jeb.040170

Stillman, J. H., and Somero, G. N. (2000). A comparative analysis of the upper thermal tolerance limits of eastern Pacific porcelain crabs, genus Petrolisthes: influences of latitude, vertical zonation, acclimation, and phylogeny. Physiol. Biochem. Zool. 73, 200-208. doi: 10.1086/316738

Stillman, J. H., and Somero, G. N. (2001). A comparative analysis of the evolutionary patterning and mechanistic bases of lactate dehydrogenase thermal stability in porcelain crabs, genus Petrolisthes. J. Exp. Biol. 204, $767-776$.

Tavaré, S. (1986). "Some probabilistic and statistical problems in the analysis of DNA sequences," in Lectures on Mathematics in the Life Sciences, ed. R. M. Miura (Providence, RI: American Mathematical Society,), 57-86.

Thurman, C. L., Faria, S. C., and McNamara, J. C. (2013). The distribution of fiddler crabs (Uca) along the coast of Brazil: implications for biogeography of the western Atlantic ocean. Mar. Biodivers. Records. 6, 1-21.

Tomanek, L., and Zuzow, M. (2010). The proteomic response of the mussel congeners Mytilus galloprovincialis and M. trossulus to acute heat-stress: implications for thermal tolerance limits and metabolic costs of thermal stress. J. Exp. Biol. 213, 3559-3574. doi: 10.1242/jeb.041228

Truchot, J. P. (1980). Lactate increases the oxygen affinity of crab hemocyanin. J. Exp. Zool. 214, 205-208. doi: 10.1002/jez.1402140212

Tyler, S., and Sidell, B. D. (1984). Changes in mitochondrial distribution and diffusion distances in muscle of goldfish upon acclimation to warm and cold temperatures. J. Exp. Zool. 232, 1-9. doi: 10.1002/jez.14023 20102

Verberk, W. C., Overgaard, J., Ern, R., Bayley, M., Wang, T., Boardman, L., et al. (2016). Does oxygen limit thermal tolerance in arthropods? A critical review of current evidence. Comp. Biochem. Physiol. 192, 64-78. doi: 10.1016/j.cbpa.2015 10.020

Wittmann, A. C., Held, C., Pörtner, H. O., and Sartoris, F. J. (2010). Ion regulatory capacity and the biogeography of Crustacea at high southern latitudes. Polar Biol. 33, 919-928. doi: 10.1007/s00300-010-0768-1

Wittmann, A. C., Pörtner, H. O., and Sartoris, F. J. (2012). A role for oxygen delivery and extracellular magnesium in limiting cold tolerance of the subantarctic stone crab Paralomis granulosa? Physiol. Biochem. Zool. 85, 285-298. doi: $10.1086 / 665328$

Zakhartsev, M. V., Johansen, T., Pörtner, H. O., and Blust, R. (2004). Effects of temperature acclimation on lactate dehydrogenase of cod (Gadus morhua): genetic, kinetic and thermodynamic aspects. J. Exp. Biol. 207, 95-112. doi: $10.1242 /$ jeb. 00708

Zavodszky, P., Jozsef, K., Svingor, A., and Petsko, G. A. (1998). Adjustment of conformational flexibility is a key event in the thermal adaptation of proteins. Proc. Nat. Acad. Sci. U.S.A. 98, 7406-7411. doi: 10.1073/pnas.95.13.7406

Zietara, M. S., Gronczewska, J., Stachowiak, K., and Skorkowski, E. F. (1996). Lactate dehydrogenase in abdominal muscle of crayfish Oronectes limosus and shrimp Crangon crangon (Decapoda: Crustacea): properties and evolutionary relationship. Comp. Biochem. Physiol. B 114, 395-401.

Conflict of Interest: The authors declare that the research was conducted in the absence of any commercial or financial relationships that could be construed as a potential conflict of interest.

Copyright (c) 2020 Faria, Bianchini, Lauer, Zimbardi, Tapella, Romero and McNamara. This is an open-access article distributed under the terms of the Creative Commons Attribution License (CC BY). The use, distribution or reproduction in other forums is permitted, provided the original author(s) and the copyright owner(s) are credited and that the original publication in this journal is cited, in accordance with accepted academic practice. No use, distribution or reproduction is permitted which does not comply with these terms. 